\title{
The Holocene dynamics of Ryder Glacier and ice tongue in north Greenland
}

\author{
Matt O'Regan ${ }^{1,2}$, Thomas M. Cronin ${ }^{3}$, Brendan Reilly ${ }^{4}$, Aage Kristian Olsen Alstrup ${ }^{5}$, Laura Gemery ${ }^{3}$, Anna Golub $^{3}$, \\ Larry A. Mayer ${ }^{6}$, Mathieu Morlighem ${ }^{7}$, Matthias Moros ${ }^{8}$, Ole L. Munk ${ }^{5}$, Johan Nilsson ${ }^{2,9}$, Christof Pearce ${ }^{10}$, \\ Henrieka Detlef $^{10}$, Christian Stranne ${ }^{1,2}$, Flor Vermassen ${ }^{1,2}$, Gabriel West ${ }^{1,2}$, and Martin Jakobsson ${ }^{1,2}$ \\ ${ }^{1}$ Department of Geological Sciences, Stockholm University, 10691, Stockholm, Sweden \\ ${ }^{2}$ Bolin Centre for Climate Research, Stockholm University, 10691, Stockholm, Sweden \\ ${ }^{3}$ Florence Bascom Geoscience Center, U.S. Geological Survey, Reston, VA, 20192, USA \\ ${ }^{4}$ Scripps Institution of Oceanography, University of California San Diego, La Jolla, CA, 92037, USA \\ ${ }^{5}$ Department of Clinical Medicine - Nuclear Medicine and PET Centre, Aarhus University Hospital, Aarhus, Denmark \\ ${ }^{6}$ Center for Coastal and Ocean Mapping, University of New Hampshire, Durham, NH, 03824, USA \\ ${ }^{7}$ Department of Earth System Science, University of California, Irvine, CA, 92697, USA \\ ${ }^{8}$ Leibniz Institute for Baltic Sea Research Warnemünde, 18119, Rostock, Germany \\ ${ }^{9}$ Department of Meteorology, Stockholm University, 10691, Stockholm, Sweden \\ ${ }^{10}$ Department of Geoscience and Arctic Research Centre, Aarhus University, 8000, Aarhus, Denmark
}

Correspondence: Matt O’Regan (matt.oregan@geo.su.se)

Received: 17 March 2021 - Discussion started: 31 March 2021

Revised: 1 July 2021 - Accepted: 7 July 2021 - Published: 24 August 2021

\begin{abstract}
The northern sector of the Greenland Ice Sheet is considered to be particularly susceptible to ice mass loss arising from increased glacier discharge in the coming decades. However, the past extent and dynamics of outlet glaciers in this region, and hence their vulnerability to climate change, are poorly documented. In the summer of 2019, the Swedish icebreaker Oden entered the previously unchartered waters of Sherard Osborn Fjord, where Ryder Glacier drains approximately $2 \%$ of Greenland's ice sheet into the Lincoln Sea. Here we reconstruct the Holocene dynamics of Ryder Glacier and its ice tongue by combining radiocarbon dating with sedimentary facies analyses along a $45 \mathrm{~km}$ transect of marine sediment cores collected between the modern ice tongue margin and the mouth of the fjord. The results illustrate that Ryder Glacier retreated from a grounded position at the fjord mouth during the Early Holocene $(>10.7 \pm 0.4 \mathrm{kacal} \mathrm{BP})$ and receded more than $120 \mathrm{~km}$ to the end of Sherard Osborn Fjord by the Middle Holocene $(6.3 \pm 0.3 \mathrm{kacal} B \mathrm{P})$, likely becoming completely land-based. A re-advance of Ryder Glacier occurred in the Late Holocene, becoming marinebased around $3.9 \pm 0.4 \mathrm{kacal}$ BP. An ice tongue, similar in extent to its current position was established in the Late
\end{abstract}

Holocene (between $3.6 \pm 0.4$ and $2.9 \pm 0.4 \mathrm{kacalBP}$ ) and extended to its maximum historical position near the fjord mouth around $0.9 \pm 0.3 \mathrm{ka}$ cal BP. Laminated, clast-poor sediments were deposited during the entire retreat and regrowth phases, suggesting the persistence of an ice tongue that only collapsed when the glacier retreated behind a prominent topographic high at the landward end of the fjord. Sherard Osborn Fjord narrows inland, is constrained by steep-sided cliffs, contains a number of bathymetric pinning points that also shield the modern ice tongue and grounding zone from warm Atlantic waters, and has a shallowing inland sub-ice topography. These features are conducive to glacier stability and can explain the persistence of Ryder's ice tongue while the glacier remained marine-based. However, the physiography of the fjord did not halt the dramatic retreat of Ryder Glacier under the relatively mild changes in climate forcing during the Holocene. Presently, Ryder Glacier is grounded more than $40 \mathrm{~km}$ seaward of its inferred position during the Middle Holocene, highlighting the potential for substantial retreat in response to ongoing climate change. 


\section{Introduction}

Mass loss from the Greenland Ice Sheet (GrIS) occurs from surface ablation (melting) and through iceberg calving (discharge) and subaqueous melt at marine-terminating glaciers. It has increased six-fold since the 1980s, contributing an estimated $13.7 \mathrm{~mm}$ to global sea level between 1972-2019 (Mouginot et al., 2019). In north and northeast Greenland (Fig. 1), ice discharge rates from marine-terminating glaciers are lower than those observed in the south and northwest (Mouginot et al., 2019). With amplified rates of high Arctic warming and the continued loss of sea ice and buttressing ice shelves, accelerated ice discharge from the northern sector of the GrIS has been identified as a particular concern for sea-level rise in the coming decades (Moon et al., 2012; Hill et al., 2018; Mouginot et al., 2019).

Marine sediment archives provide unique insights into the past extent and dynamics of Greenland's marine-based ice margin, including the sensitivity and environmental controls on the stability of outlet glaciers and their floating ice tongues (Jakobsson et al., 2018, 2020; Wangner et al., 2018; Reilly et al., 2019; Vermassen et al., 2020). Combined with analyses of ice cores (Vinther et al., 2009; Lecavalier et al., 2017), terrestrial and marine mapping of glacial limits (Funder et al., 2011b), and other paleoclimate time series (Briner et al., 2016), marine sediment archives allow us to investigate the response of the GrIS to natural climate variability over timescales that exceed the length of direct satellite observations and other historical records. An understanding of how marine-terminating glaciers responded to past climate change and ultimately elucidating the geologic and environmental controls on their behavior are critical to reduce uncertainties in future sea-level predictions (Bamber et al., 2019).

After the Last Glacial Maximum, the GrIS receded dramatically through the Early (11.7-8.2 ka cal BP) and Middle Holocene (8.2-4.2 ka cal BP) when Arctic summer air temperatures were $\sim 1-3{ }^{\circ} \mathrm{C}$ above 20th century averages (Kaufman et al., 2004; Miller et al., 2010; Briner et al., 2016). The GrIS reached its minimum extent near the end of the Middle Holocene or sometime near the beginning of the Late Holocene (4.2-0 ka cal BP) (Young and Briner, 2015). The Lincoln Sea, which surrounds much of northern Greenland, hosts some of the most persistent and harsh sea-ice conditions in the Arctic today. However, many terrestrial glacial (Kelly and Bennike, 1992; Landvik et al., 2001; Möller et al., 2010; Funder et al, 2011a; Larsen et al., 2019) and lacustrine paleoclimate studies (Olsen et al., 2012) show warmer climatic conditions, reduced glacial ice extent, and more open water conditions along the north Greenland coast during the Holocene thermal maximum (11.0-5.5 ka cal BP). Due to difficulties in accessing the Lincoln Sea, there are no marine records documenting glacier dynamics north of Petermann Glacier (Reilly et al., 2019) that can be combined with these land-based studies.
In the summer of 2019, during the Ryder 2019 expedition, the Swedish icebreaker Oden became the first vessel to enter the unchartered waters of Sherard Osborn Fjord, which connects Ryder Glacier with the Lincoln Sea (Fig. 1). Ryder Glacier drains about $2 \%$ of Greenland's ice sheet and is one of four major marine-terminating glaciers in this sector of the GrIS (Fig. 1). Ryder and Petermann glaciers in the northwest and Nioghalvfjerdsfjorden Glacier in the northeast are the only remaining Greenland outlet glaciers that have large, intact floating ice tongues, which are believed to exert an important buttressing force that slows glacier flow (Mottram et al., 2019). Ryder's ice tongue is $25 \mathrm{~km}$ long and has been relatively stable during the last 70 years, showing a net advance of about $43 \mathrm{~m} \mathrm{yr}^{-1}$ between 1948 and 2015 (Hill et al., 2018).

Here we combine radiocarbon dating with the analysis of lithofacies in six marine sediment cores that form a $\sim 45 \mathrm{~km}$ long transect extending from the modern ice tongue margin of Ryder Glacier to the mouth of Sherard Osborn Fjord. We integrate these results with established phases of ice recession and regrowth in this sector of northern Greenland, providing the first insights into the dynamic behavior of Ryder Glacier and its ice tongue during the Holocene.

\section{Geologic, oceanographic, and glaciologic setting}

Sherard Osborn Fjord is $\sim 17 \mathrm{~km}$ wide and extends $\sim 81 \mathrm{~km}$ from the modern grounding zone of Ryder Glacier out towards the Lincoln Sea. Ryder Glacier is currently grounded below sea level, with an ice tongue that extends $\sim 55 \mathrm{~km}$ out from the grounding zone (Fig. 2). Bathymetric mapping during the Ryder 2019 expedition revealed two prominent sills crossing the fjord (Jakobsson et al., 2020) (Fig. 2). These sills bound a basin that has a maximum depth of $890 \mathrm{~m}$. The outer sill has little sedimentary cover and appears to be a bedrock feature, while the inner sill is interpreted as a sedimented former glacial grounding zone (Jakobsson et al., 2020), potentially developed on a pre-existing bedrock high.

The sill depths on the outer fjord are $475 \mathrm{~m}$ on the east and $375 \mathrm{~m}$ on the west (Fig. 2). The inner sill has a $\sim 6.2 \mathrm{~km}$ wide central region that ranges in depth from 193 to $300 \mathrm{~m}$, with a $\sim 1 \mathrm{~km}$ wide channel on the eastern side that extends to a depth of $390 \mathrm{~m}$. The modern ice tongue terminus of Ryder Glacier is located approximately $5 \mathrm{~km}$ landward of the inner sill. Despite these bathymetric barriers, waters of Atlantic origin that circulate through the Lincoln Sea are found between the two sills at depths greater than $350 \mathrm{~m}$ (Fig. 3; Jakobsson et al., 2020). These relatively warm $\left(>0.3{ }^{\circ} \mathrm{C}\right)$ and saline ( $>34.7$ ) waters are constrained by the inner sill, with only a small amount of warmer water flowing across the inner sill through the $<1 \mathrm{~km}$ wide and $390 \mathrm{~m}$ deep channel to be strongly mixed with glacially derived meltwater.

Sherard Osborn Fjord cuts into the Paleozoic Franklinian Basin that extends over $2000 \mathrm{~km}$ from the Canadian Arctic to eastern north Greenland (Henriksen and Higgins, 


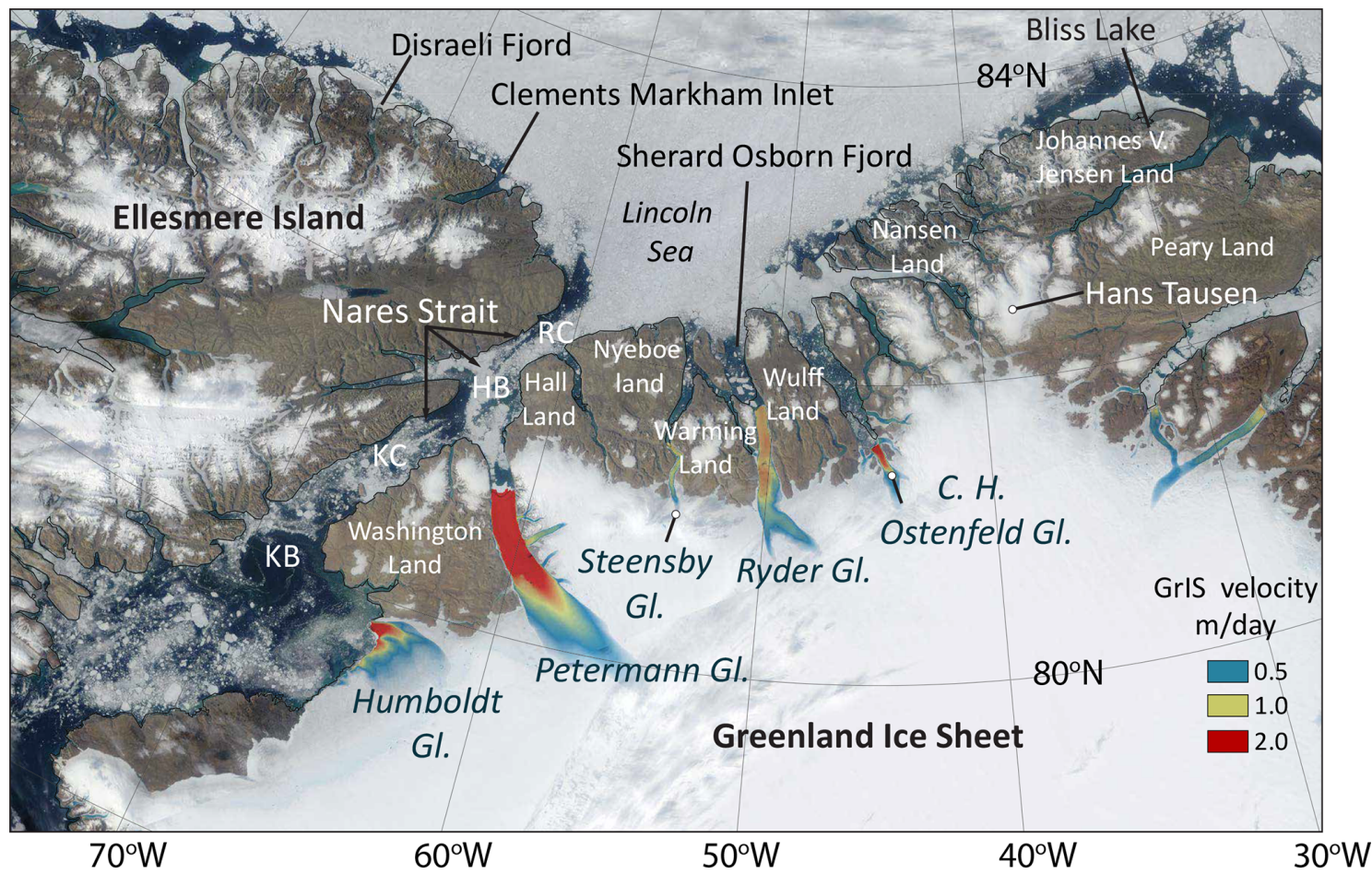

Figure 1. Satellite view of north Greenland and Ellesmere Island from 30 July 2019. Velocities of outlet glaciers are from Sentinel-1, winter campaign 2019/2020, version 1.3 (Nagler et al., 2015). Robeson Channel (RC), Hall Basin (HB), Kennedy Channel (KC), and Kane Basin $(\mathrm{KB})$.

2000). Along the north Greenland coast, deposition in the Franklinian Basin occurred in a passive margin environment throughout the latest Precambrian to Devonian, with shallow water carbonate shelf sediments found to the south and siliciclastic slope and deep-water sediments in the north (Henriksen et al., 2009). Exposed sedimentary bedrock between the present GrIS margin and the terminus of the floating ice tongue of Ryder Glacier is composed of Cambrian and Silurian carbonate shelf sediments. Further seaward, Silurian sands and siltstones deposited in a deeper water turbiditic environment are found on the lowlands of Nyeboe Land and Wulff Land (Henriksen and Higgins, 2000). Older, deformed Cambrian deep-water calcareous mudstones and sandy turbidites cap the outer headlands of Nyeboe Land and Wulff Land and are part of the $600 \mathrm{~km}$ long E-W trending north Greenland fold belt that formed near the end of the Devonian and Ellesmerian Orogeny (Higgins et al., 1998) (Fig. 2).

Terrestrial mapping of glacial landforms and marine limits across Nyeboe Land, Warming Land, and Wulff Land has defined three regional glacial events from the end of the Pleistocene (late Weichselian) through the Holocene (Kelly and Bennike, 1992). The oldest marginal ice limits that are traced across north Greenland belong to the Kap Fulford Stade (Kelly and Bennike, 1992). During this time, the GrIS extended across the southern parts of many peninsulas, with outlet glaciers flowing to the outer limits of many of the fjords. Radiocarbon dates from marine macrofossils sampled by Kelly and Bennike (1992) at Kap Fulford (Station 31; $10030 \pm 175$ and $9390 \pm 90{ }^{14} \mathrm{CBP}$ ) and freshwater algae from northern Wulff Land (Station 43; $10480 \pm 90{ }^{14} \mathrm{C} \mathrm{BP}$ ) provide minimum age estimates for the retreat of glacial ice of the Kap Fulford Stade to the latest Pleistocene to Early Holocene (> 10.5 ka cal BP) (Kelly and Bennike, 1992) (Table 1, Fig. 2).

A second set of ice marginal deposits are found along many of the fjords $20-60 \mathrm{~km}$ inland from the Kap Fulford Stade. These are assigned to the Warming Land Stade, representing a standstill of outlet glaciers draining the retreating ice front. Regionally, the age of the Warming Land Stade is bracketed between $>9.5$ to $8.0 \mathrm{ka}$ cal BP (Kelly and Bennike, 1992). Many glacially dammed lakes formed during the Warming Land Stade as glaciers continued to occupy the fjord systems while the ice margin retreated on land (Kelly and Bennike, 1992). For example, an ice-dammed lake formed on Wulff Land in the central lowlands between Ryder and C. H. Ostenfeld glaciers (Fig. 1). The most proximal minimum age constraints for the Warming Land Stade in Sherard Osborn Fjord come from western Warming Land, where marine macrofossils in sediments younger than the ice margin deposits provide an age of $8210 \pm 120{ }^{14} \mathrm{CBP}$ (Station 36; Kelly and Bennike, 1992). On southeastern Warming Land molluscs from a marine silt returned an age of 
Table 1. Key radiocarbon dates originally used to constrain the ages of glacial stages in the vicinity of Sherard Osborn Fjord. Index numbers refer to original site numbers given in Kelly and Bennike (1992) with locations shown in Fig. 2. Details of the sampling sites are from Kelly and Bennike (1985) and Bennike and Kelly (1987). Ages were re-calibrated with IntCal 20 (41, 43) or Marine20 using a $\Delta R 300 \pm 300$, which is consistent with the new calibrated radiocarbon dates presented in this article. Calibrated ages are rounded to 10 years.

\begin{tabular}{|c|c|c|c|c|}
\hline No. & Relevance & Lab. ID & ${ }^{14} \mathrm{C}$ age (year) & Mean and $1 \sigma$ range (cal BP) \\
\hline \multirow[t]{2}{*}{31} & Kap Fulford Stade & K-4339 & 10030 & 108 \\
\hline & \multicolumn{4}{|c|}{ Shells of Portlandia arctica from marine silts at an elevation of $87 \mathrm{~m}$} \\
\hline \multirow[t]{2}{*}{31} & Kap Fulford Stade & HAR-6289 & $9390 \pm 90$ & $9690 \pm 400$ \\
\hline & \multicolumn{4}{|c|}{ Shells of Hiatella arctica from marine silts at $92-93 \mathrm{~m}$} \\
\hline \multirow[t]{2}{*}{34} & Steensby Stade & K-4380 & $4870 \pm 80$ & $4560 \pm 410$ \\
\hline & \multicolumn{4}{|c|}{ Shells of Mya truncata and $H$. arctica from marine silts at $24 \mathrm{~m}$} \\
\hline \multirow[t]{2}{*}{36} & Warming Land Warming Land Stade & HAR-6290 & $8210 \pm 120$ & $8210 \pm 370$ \\
\hline & \multicolumn{4}{|c|}{ Shells of $M$. truncata and $H$. arctica from outcropping marine silts at $68-70 \mathrm{~m}, 12 \mathrm{~km}$ behind ice front } \\
\hline \multirow[t]{2}{*}{40} & Warming Land Warming Land Stade & HAR-6287 & $6480 \pm 100$ & $6420 \pm 350$ \\
\hline & \multicolumn{4}{|c|}{ Shells of $M$. truncata from marine silts at $26 \mathrm{~m}$ that are younger than ice margin deposits } \\
\hline \multirow[t]{2}{*}{41} & Steensby Stade & $\mathrm{K}-4573$ & $5100 \pm 130$ & $5830 \pm 170$ \\
\hline & \multicolumn{4}{|c|}{ Salix twigs from the base of sandy peat at $275 \mathrm{~m}$; station located $100 \mathrm{~m}$ from margin of outlet glacier } \\
\hline \multirow[t]{2}{*}{43} & Kap Fulford Stade & GU-2588 & $10480 \pm 90$ & $12380 \pm 270$ \\
\hline & \multicolumn{4}{|c|}{ Filamentous green algae from a silt lens embedded in gravelly diamicton at $72 \mathrm{~m}$} \\
\hline \multirow[t]{2}{*}{44} & Warming Land Stade & $\mathrm{K}-4374$ & $8000 \pm 115$ & $7990 \pm 330$ \\
\hline & \multicolumn{4}{|c|}{ Shells of $M$. truncata and $H$. arctica from a sand layer overlying folded silt and sand at $62 \mathrm{~m}$} \\
\hline
\end{tabular}

$6480 \pm 100{ }^{14}$ C BP (Station 40; Kelly and Bennike, 1992), implying that ice had retreated further inland than this position by that time. On the eastern edge of Wulff Land, outlet glaciers built a series of deltas in the ice-dammed lake during the Warming Land Stade. Marine macrofossils in the lowest delta are dated to $8000 \pm 115^{14} \mathrm{C} \mathrm{BP}$ (Station 44), indicating that the retreat of $\mathrm{C}$. H. Ostenfeld Glacier and drainage of the glacial lake occurred after this time (Kelly and Bennike, 1992). The ice margin continued to retreat following the Warming Land Stade. In the vicinity of Ryder Glacier, it likely reached a position equivalent to its modern one by the Middle Holocene $\sim 6 \mathrm{ka}$ cal BP before receding even further inland (Kelly and Bennike, 1992).

The Steensby Stade marks the most recent re-advance of the ice margin outlet glaciers and local ice caps to their maximum positions since the Kap Fulford Stade. Its onset is poorly dated and occurred sometime during neoglacial cooling following the Holocene thermal maximum. At the GrIS margin to the north of Ryder Glacier, peat deposits over which the ice margin advanced provide an age of $5100 \pm$ $130{ }^{14} \mathrm{C} \mathrm{BP}$ (Station 41), while at Steensby Glacier, reworked marine macrofossils in lateral moraines yield an age of $4870 \pm 80{ }^{14}$ C BP (Station 34; Kelly and Bennike, 1992). Despite uncertainty surrounding the onset of the Steensby Stade and subsequent dynamics of Ryder Glacier through the Late Holocene, the maximum extent is believed to coincide with historical observations that place the terminus of outlet glaciers and ice tongues near the mouth of many of the major fjords. This is true for Ryder's ice tongue, which was positioned near the outer margin of Sherard Osborn Fjord in 1917 by the Danish geologist and explorer Lauge Koch (Koch, 1928) (Fig. 2). Between 1917 and 1947, Ryder's ice tongue retreated to near its current position (Davies and Krinsley, 1962; Higgins, 1990) and has remained relatively stable, even exhibiting a net advance of $43 \mathrm{~m} \mathrm{yr}^{-1}$ between 1948-2015 (Hill et al., 2018).

\section{Materials and methods}

\subsection{Marine sediment cores}

Sediment cores from Sherard Osborn Fjord were collected during the 37 d Ryder 2019 expedition (5 August10 September 2019). Between 13 and 25 August, unusually light sea-ice conditions allowed Oden to occupy nine coring stations and systematically map the fjord (Fig. 2; Jakobsson et al., 2020). Coring was conducted using a $12 \mathrm{~m}$ long piston core (PC) and small (1-2 m) trigger weight core (TWC), as well as a $6 \mathrm{~m}$ long gravity core (GC). Piston and gravity cores were collected in liners with an inner/outer diameter of $100 / 110 \mathrm{~mm}$, while TWCs were collected in narrower $(80 / 88 \mathrm{~mm})$ liners.

Here we focus on cores obtained from five stations that were positioned on topographic highs, with two radiocarbon dates coming from a sixth station on the outer sill. The five main stations form a $45 \mathrm{~km}$ long transect extend- 
Table 2. Locations, water depths, and lengths of cores used in this study.

\begin{tabular}{llllrr}
\hline Station & Core ID & Latitude $\left({ }^{\circ} \mathrm{N}\right)$ & Longitude $\left({ }^{\circ} \mathrm{E}\right)$ & Water depth $(\mathrm{m})$ & Core length $(\mathrm{m})$ \\
\hline 6 & Ryder19-6-GC1 & 82.0095 & -51.7408 & 633 & 4.93 \\
\hline 7 & Ryder19-7-GC1 & 81.9532 & -51.5760 & 551 & 5.19 \\
& Ryder19-7-PC1 & 81.9518 & -51.5878 & 559 & 8.96 \\
& Ryder19-7-TWC1 & 81.9518 & -51.5878 & 559 & 0.96 \\
\hline \multirow{2}{*}{8} & Ryder19-8-GC1 & 81.8947 & -51.1365 & 228 & 4.98 \\
& Ryder19-8-PC1 & 81.8928 & -51.1315 & 238 & 8.97 \\
\hline 9 & Ryder19-9-GC1 & 81.8843 & -50.9848 & 271 & 5.89 \\
& Ryder19-9-PC1 & 81.8908 & -50.9682 & 274 & 8.72 \\
\hline 10 & Ryder19-10-GC1 & 82.2713 & -52.0165 & 272 & 2.87 \\
\hline 11 & Ryder19-11-GC1 & 82.2682 & -52.5038 & 208 & 1.34 \\
\hline
\end{tabular}

ing from the edge of the modern ice tongue to the outer sill of Sherard Osborn Fjord (Table 2, Fig. 2). Sub-bottom profiles were acquired across the coring sites with Oden's Kongsberg SBP $120\left(3^{\circ} \times 3^{\circ}\right)$ chirp sonar using a $2.5-7 \mathrm{kHz}$ pulse. These profiles show that a relatively thin $(<10-15 \mathrm{~m})$ drape of sediments exists on top of the acoustic basement (Fig. 4). This basement surface could be either sedimentary bedrock or highly consolidated sedimentary units like till. Hogan et al. (2020) illustrated that in Petermann Fjord, lower-frequency air gun seismic data were required to differentiate bedrock from more lithified sediments and till.

The unsplit sediment cores were allowed to equilibrate to room temperature $\left(\sim 20^{\circ} \mathrm{C}\right)$ and logged shipboard on a Geotek multi-sensor core logger (MSCL). The MSCL provided downcore measurements $(1 \mathrm{~cm}$ sampling interval) of bulk density (using gamma-ray attenuation) and magnetic susceptibility. Bulk density is controlled by sediment porosity and grain composition (grain density). In predominantly lithogenic and normally consolidated marine sediments, variability in bulk density is a function of grain-sizedriven changes to porosity (coarser sediments $=$ lower porosity $=$ higher bulk density). Magnetic susceptibility is a useful proxy for the input of siliciclastic versus biogenic/organic sediments, and in dominantly lithogenic sediments it can be used to discriminate between provenance and grain size (Hatfield et al., 2017; Reilly et al., 2019). Gamma-ray attenuation was measured using a ${ }^{137} \mathrm{Cs}$ source with a $5 \mathrm{~mm}$ collimator and a $10 \mathrm{~s}$ count time. Magnetic susceptibility was measured with a $125 \mathrm{~mm}$ Bartington loop sensor using a $1 \mathrm{~s}$ acquisition time. An empirical volume correction was applied to account for the difference between the core diameter $\left(D_{\mathrm{C}}\right)$ and the loop diameter $\left(D_{\mathrm{L}}\right)$. The volume-specific magnetic susceptibility $\left(\kappa, 10^{-5} \mathrm{SI}\right)$ is defined as

$\kappa=\kappa_{\text {(uncorrected) }} / \kappa_{\text {(rel) }}$,

where

$\kappa_{(\mathrm{rel})}=4.8566\left(D_{\mathrm{C}} / D_{\mathrm{L}}\right)^{2}-3.0163\left(D_{\mathrm{C}} / D_{\mathrm{L}}\right)-0.6448$.
The mass-specific magnetic susceptibility $(\chi)$ was calculated by dividing $\kappa$ by the bulk density.

After logging, piston and gravity cores were split into working and archive half sections. Archive halves were described and imaged using a digital line-scanning camera on the MSCL, while the working half was sampled for shorebased analyses. Split sections were wrapped in plastic film, placed in D-tubes and stored in a refrigerated container $\left(4{ }^{\circ} \mathrm{C}\right)$ until they were returned to Stockholm University's refrigerated core storage facility. TWCs remained unsplit and placed directly into the refrigerated container.

Following the expedition, all archive halves were analyzed on an Itrax X-ray fluorescence (XRF) core scanner at the Department of Geological Sciences, Stockholm University. Measurements were performed with a Mo tube set to $55 \mathrm{kV}$ and $50 \mathrm{~mA}$ with a downcore measurement resolution of $2 \mathrm{~mm}$ and a counting time of $15 \mathrm{~s}$. Here we only present the raw counts of calcium $(\mathrm{Ca})$ as a proxy for detrital input from the surrounding Cambrian and Silurian carbonate bedrock terrain.

Computed tomography (CT) scanning was performed on selected archive sections and unsplit TWCs at the Department of Nuclear Medicine and PET Centre of Aarhus University Hospital in Denmark using a Siemens Biograph Vision $600 \mathrm{PET} / \mathrm{CT}$. The CT scan parameters were as follows: $120 \mathrm{kV}, 400 \mathrm{Eff}$ mAs (no CARE Dose4D), $200 \mathrm{~mm}$ field of view, $0.6 \mathrm{~mm}$ slice thickness, and filter kernel B60s (sharp). Images were processed using SedCT MATLAB tools to obtain a coronal slice through the central region of each core at an effective pixel resolution of $0.5 \times 0.5 \mathrm{~mm}$ (Reilly et al., 2017). Clasts with $>1 \mathrm{~mm}$ diameter were automatically counted from the 3-dimensional CT data, binned into $2 \mathrm{~cm}$ intervals, and normalized by core volume using the algorithm of Reilly et al. (2019) which provides an objective proxy for ice-rafted debris (IRD) concentration in glaciomarine lithofacies deposited beyond the limit of grounded ice. 


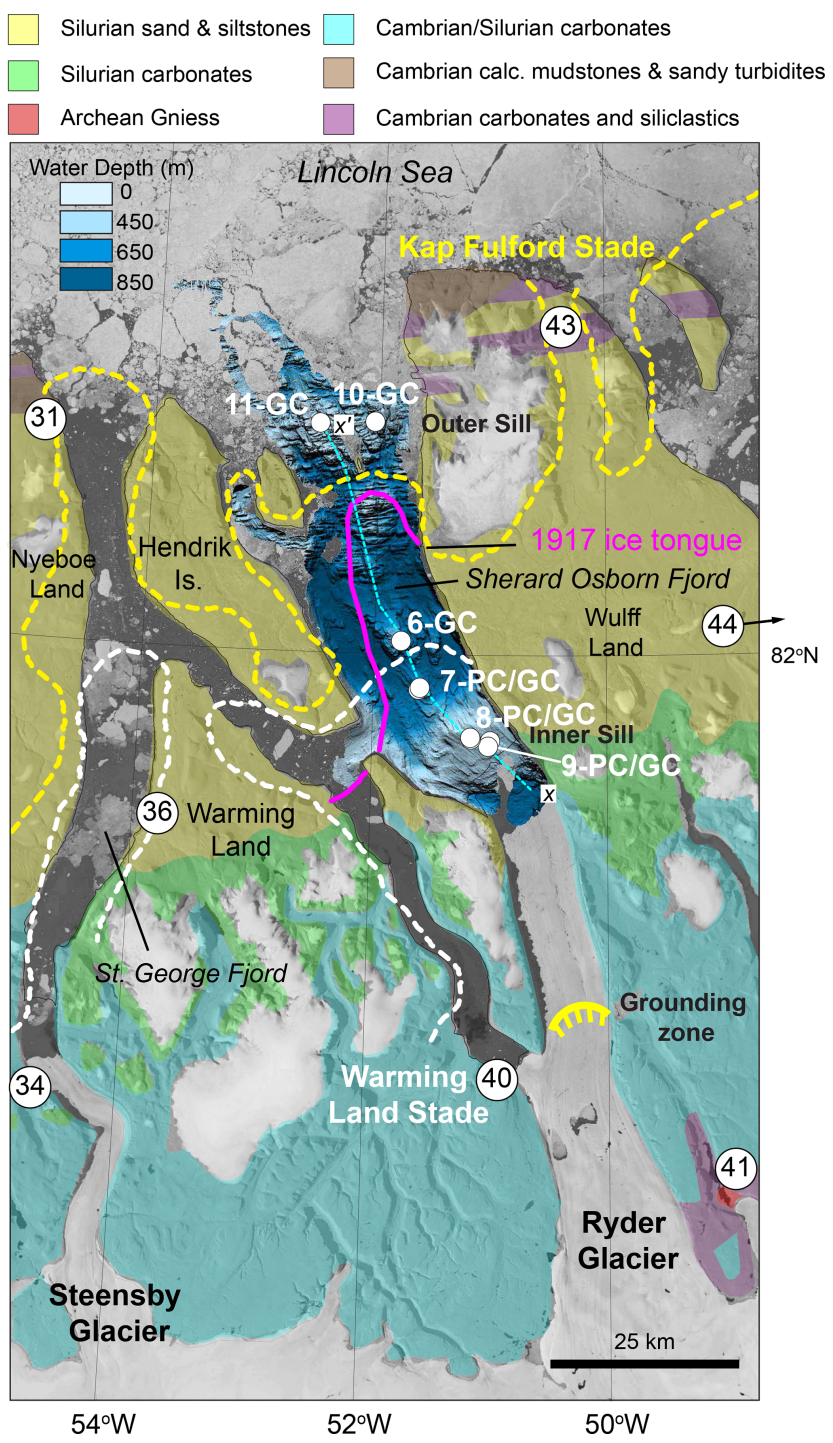

Figure 2. Landsat image of Sherard Osborn Fjord from 30 July 2019 showing locations of cores discussed in this study. Bedrock geology is from Henriksen et al. (2009). Bathymetry of Sherard Osborn Fjord was collected during the Ryder 2019 expedition (Jakobsson et al., 2020). Ice limits for the Kap Fulford (yellow) and Warming Land (white) stades are redrawn from Kelly and Bennike (1992). The extent of Ryder's ice tongue in 1917 (pink) is re-drawn from Koch (1928). Numbers refer to key locations of radiocarbon dates used by Kelly and Bennike (1992) to constrain Holocene ice margin positions (Table 1). The dashed cyan line ( $x-$ $x^{\prime}$ ) marks the location of the oceanographic profile in Fig. 3.

A total of 29 grain size measurements were made on core 6-GC to broadly characterize grain size spectra in different lithologic units. Measurements were performed using a Malvern Mastersizer 3000 laser diffraction particle size analyzer at the Department of Geological Sciences, Stockholm University. Wet samples were immersed in a dispersing agent $(<10 \%$ sodium hexametaphosphate solution) and

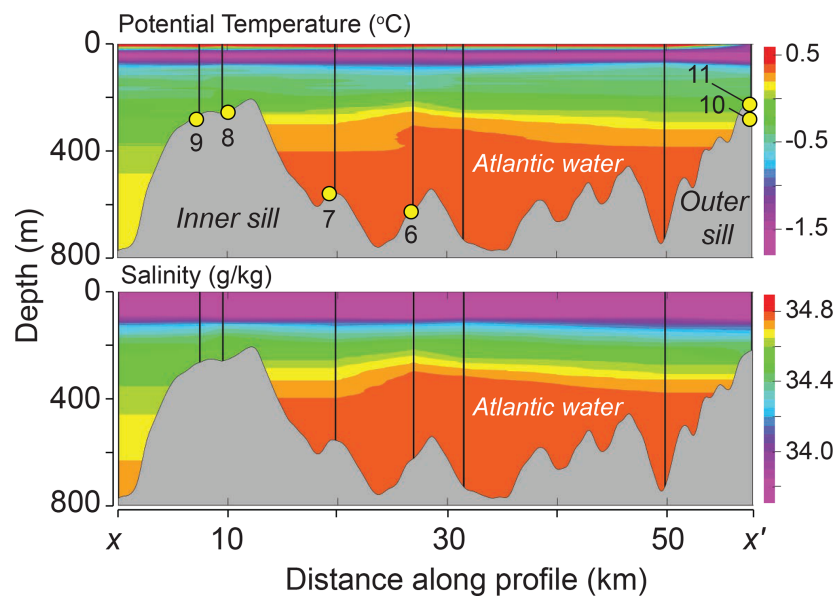

Figure 3. Potential temperature and salinity profiles illustrating the distribution of Atlantic water in Sherard Osborn Fjord. Vertical black lines are positions of CTD (conductivity, temperature, and depth) casts conducted during Ryder 2019. Yellow circles are the locations of coring sites. The position of site 10 on the outer sill is projected, as this profile does not cross its location (see Fig. S1 in the Supplement for the details on the location of the oceanographic profile).

placed in an ultrasonic bath to disaggregate particles before being poured into the Malvern measurement chamber.

\subsection{Composite depth scales}

The first attempts at coring in Sherard Osborn Fjord illustrated that near-surface sediments were very soft. The top of the coring tools were sinking below the seafloor, resulting in poor and variable recovery of near-surface sediments. At stations 7,8 , and 9, multiple coring tools were deployed, and sediments were recovered using all of these devices. A composite depth scale was developed for each station to ensure that measurements from the different cores could be integrated. The composite depth scales were developed through the correlation of the MSCL bulk density, magnetic susceptibility, and XRF-scanning (mainly Ca content) data and additionally through visual correlation using the $\mathrm{CT}$ images (tie points for the composite depth scale are provided in Table $\mathrm{S} 1$ in the Supplement).

The piston core at each station was used as the reference depth scale. Depths of the gravity and trigger weight cores were stretched, or compressed, between tie points to the piston cores. At stations 7 and 9, the piston core recovered sediments closer to the seafloor than the gravity or trigger weight cores. At station 8, the correlation of MSCL and XRF data indicates that the gravity core recovered $40 \mathrm{~cm}$ of near-surface sediments that were either not recovered or lost from the top of the piston core. 

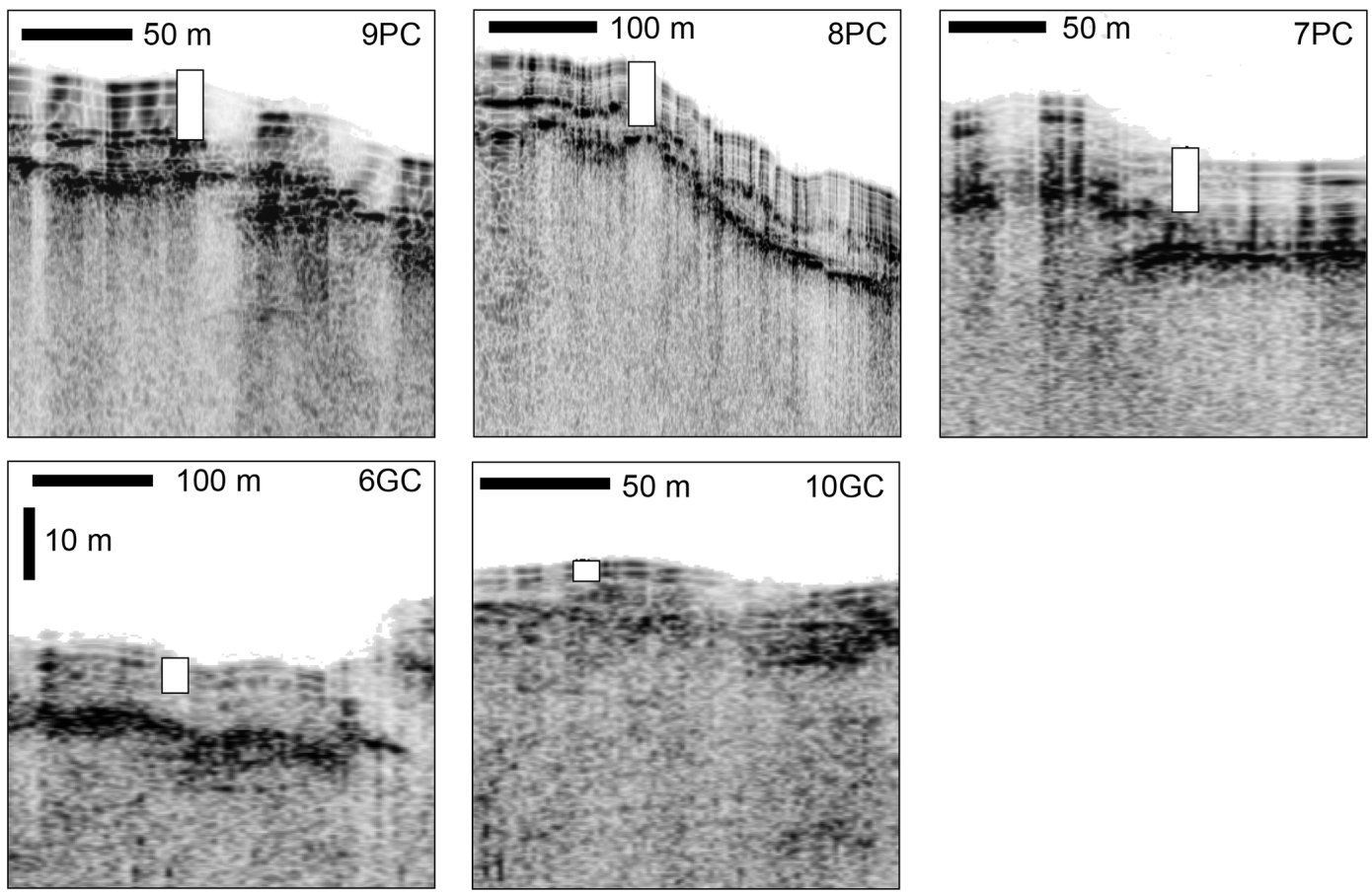

Figure 4. Sub-bottom profiles across coring stations in Sherard Osborn Fjord illustrating the amount of the sedimentary cover on top of acoustic basement penetrated by each core.

\subsection{Radiocarbon dating}

Radiocarbon measurements $\left({ }^{14} \mathrm{C}\right)$ were made on 48 samples (Table 3). Shipboard and post-cruise sampling focused on constraining the ages for lithologic units. Most radiocarbon dates were obtained from 300 specimens of the benthic foraminifera Cassidulina neoteretis (see Cronin et al., 2019; Cage et al., 2021, for discussions of this foraminiferal species in the Arctic and Nordic seas respectively). A total of 16 dates were obtained from mixed benthic foraminifera (including $C$. neoteretis, $C$. reniforme, O. tener, E. excavatum clavata) and one date from Cibicides lobatulus (Table 3). Additionally, four dates were made from specimens of the planktic foraminifera Neogloboquadrina pachyderma. All radiocarbon measurements were performed at the National Ocean Sciences Accelerator Mass Spectrometry (NOSAMS) facility at Woods Hole Oceanographic Institution, Massachusetts, USA. Calibration of the radiocarbon dates was performed using OxCal v. 4.4 (Bronk Ramsey, 2009) and the Marine20 calibration curve (Heaton et al., 2020).

There is no a priori information on the local marine reservoir correction $(\Delta R)$ for Sherard Osborn Fjord or the Lincoln Sea. Estimates of $\Delta R$ for nearby regions vary widely and have been derived using different marine calibration curves. Results from three pre-bomb living molluscs collected in the vicinity of Thule suggest a $\Delta R$ of $5 \pm 50$ years (Mörner and Funder, 1990). Kelly and Bennike (1992) ap- plied 150-year $\Delta R$ for marine macrofossils from the region surrounding Ryder Glacier, as suggested for areas of northernmost Greenland by Funder (1982). However, Coulthard et al. (2010) found an average $\Delta R$ of $335 \pm 85$ years (using Marine09; Reimer et al., 2009) based on 24 molluscs from the northwestern Canadian Arctic Archipelago, which includes the northern and western coasts of Ellesmere Island. Reilly et al. (2019) argued that a $\Delta R$ of 770 years (using Marine13; Reimer et al., 2013) provided the best fit between a stacked paleosecular variation record from Petermann Fjord sediments and a North Atlantic reference curve. This large $\Delta R$ was also consistent with offsets between radiocarbon dates on planktic and benthic foraminifera and ${ }^{210} \mathrm{~Pb}$-derived chronologies for the past 100 years. In summary, estimates used in the literature range from 0-770 years. In this study we have applied the new Marine20 calibration curve (Heaton et al., 2020), which results in ages that are $\sim 150$ years younger than equivalent Holocene ${ }^{14} \mathrm{C}$ ages calibrated using Marine09 or Marine13. Taking this into consideration we have applied a $\Delta R$ of $300 \pm 300$ years. This broad range provides a large uncertainty envelope. The upper bound approaches the older offset found by Reilly et al. (2019) for Petermann Fjord (770 years using Marine13, which equates to $\sim 620$ years using Marine20), and the lower bound approaches the 150 years (which equates to $\sim 0$ years using Marine20) commonly used to reconstruct terrestrial ice margins in the area (Kelly and Bennike, 1992; Young and Briner, 2015). The mean calibrated ages obtained using a 
$\Delta R$ of $300 \pm 300$ years (equivalent to $\sim 450$ years using Marine13) provide a suitable estimate for sites that are influenced by Atlantic waters. This dependency on water mass is one of the underlying problems in determining an applicable local reservoir correction. For example, the paired benthic and planktic foraminifera samples we ran revealed offsets of 470-570 years in 6-GC and 7-PC which are currently bathed in Atlantic waters, and 0 to 200 years in $10-\mathrm{GC}$ which lies closer to the mixed surface layer (Fig. 3; Table 3). Additional work is needed to resolve the issue of local marine reservoir offsets in the region, their dependency on water mass, and how they may have changed through time.

\section{Results}

\subsection{Lithostratigraphic units}

Data from the MSCL, XRF-scanning data, and CT imaging are used to identify six major lithologic units that are correlated from the fjord mouth (10-GC) to the inner bathymetric sill lying seaward of the modern ice tongue (cores 8-PC and 9-PC) (Figs. 5 and 6). A sixth core, 11-GC, located on the outer sill in the shallowest water depth $(208 \mathrm{~m}$ b.s.l., below sea level), did not contain the same lithostratigraphic units, and only the basal radiocarbon date is used as a constraint for Early Holocene ice retreat. Composite depths for the base of the lithostratigraphic units are found in Table S2.

LU6. The lowermost lithologic unit (LU6) was recovered in 7-PC, 8-PC, and 9-PC. It has moderately high but variable $\mathrm{Ca}$ contents and is a coarse-grained, poorly sorted diamicton containing abundant gravel (2-64 mm) and cobble-sized $(64-256 \mathrm{~mm})$ clasts with a high bulk density $\left(>2 \mathrm{~g} / \mathrm{cm}^{3}\right)$ (Figs. 5 and 7). The mass-specific magnetic susceptibility is considerably higher in LU6 compared to the overlying LU5, generally exceeding $80-100 \times 10^{-8} \mathrm{~m}^{3} / \mathrm{kg}$. Less than $5 \mathrm{~cm}$ of this unit was recovered in 9-PC, with greater recovery in 7-PC $(54 \mathrm{~cm})$ and 8-PC $(>135 \mathrm{~cm})$. The upper boundary with LU5 is abrupt in 8-PC and gradual in 7-PC. In 9-PC, the thin LU6 and lowermost LU5 sediments are laminated, deformed, and contain two large dropstones, making it difficult to determine the nature of the boundary. The LU6-LU5 boundary is marked by a pronounced up-core decrease in bulk density and mass-specific magnetic susceptibility. Two subunits (LU6a and LU6b) are recognized in the longer sequences from 7-PC and 8-PC. These subunits are separated by a sharp boundary (Figs. 6 and 7). Sediments from LU6a have a lower bulk density $\left(2.0-2.2 \mathrm{~g} / \mathrm{cm}^{3}\right)$ compared to LU6b $\left(2.2-2.5 \mathrm{~g} / \mathrm{cm}^{3}\right)$ and lower clast abundance. LU6b is a massive clast-supported diamicton, while LU6a contains lenses or intervals of visibly deformed fine-grained layers. Given the succession from a massive to a deformed diamicton, we interpret these units as being deposited beneath grounded ice (Figs. 6 and 7). Although we recognize that deformed diamictons can be deposited beneath grounded ice (deforma- tion till) or proximal to the grounding line (gravity flow deposits), both options imply deposition close to the grounding zone.

LU5. The defining characteristics of LU5 are pronounced millimeter- to centimeter-scale laminations and the absence of bioturbation. Laminae are sometimes visible in the split core sections as alternating reddish-brown and lighter tancolored layers (Fig. 6). The laminations are best defined by variations in $\mathrm{Ca}$ and bulk density. Where visible to the naked eye, the lighter tan-colored laminations are enriched in $\mathrm{Ca}$ and denser (lighter in CT-scanning images) (Fig. 6). $\mathrm{Ca}$-enriched layers are skewed towards medium and coarse silts, while laminae with lower $\mathrm{Ca}$ abundance are skewed towards fine silt and clay (Fig. 8). The higher bulk density of the light-colored laminae is likely caused by the coarser grain size and higher detrital carbonate content, which has a higher grain density compared to quartz and clay minerals. LU5 has a low abundance of irregularly spaced clasts $>1 \mathrm{~mm}$ that are more prevalent near the base of the unit (Fig. 5). In cores 10$\mathrm{GC}, 7-\mathrm{PC}$, and 6-GC, there is a notable up-core decrease in the bulk density, Ca-content, and lamina thickness of LU5. Mass-specific magnetic susceptibility also increases up-core, as the relative Ca-abundance decreases, consistent with a larger contribution from siliciclastic sediments. In 6-GC and 7-PC, these long-term trends are interrupted by a $0.50-1.0 \mathrm{~m}$ thick interval with elevated $\mathrm{Ca}$ contents and thicker laminae found near the top of the unit.

At the two stations from the inner sill, 8-PC (238 m b.s.1.) and 9-PC (274 $\mathrm{m}$ b.s.1.), LU5 is considerably thinner than in 6-GC (633 m b.s.1.) and 7-PC (559 m b.s.l.), which lie further seaward and in deeper water depths (Fig. 5). CT images illustrate that laminations in much of LU5 are wavy to lenticular in nature (Figs. 6 and 7). Throughout LU5, the laminations are disrupted by numerous small-scale normal faults with occasional evidence of truncation suggesting erosion. This is common throughout LU5 in 8-PC and 9-PC and very common in the lowermost 1-2 $\mathrm{m}$ of 7-PC (see example from 9-PC-6 in Fig. 7 and the Supplement for additional examples). In 6-GC and 7-PC, faulting in LU5 is more pronounced than in the overlying laminated sequence of LU4 (Figs. 6 and 7). Laminations become less convoluted and more planar towards the top of LU5. On the outer sill (10-GC), LU5 is also comparatively thin, containing highly fractured and wispy laminations that are truncated or eroded in some intervals. The base of LU5 in 10-GC is dominantly composed of sand- and gravel-sized material.

The wavy and lenticular nature of laminations in much of LU5 is interpreted as evidence for traction processes under the influence of bottom water currents. We interpret this unit as a meltwater-generated laminated facies that transitions from a grounding line proximal deposit at the base to distal at the top. The $\mathrm{Ca}$ enrichment arises from increased inputs of detrital carbonate eroded from the surrounding Cambrian and Silurian bedrock and is more common in the grounding zone proximal base of the sequence. Evidence for truncation 
Table 3. Raw and calibrated radiocarbon dates and the type of material analyzed. All data were calibrated using a $\Delta R 300 \pm 300$ years. Asterisks highlight ages deemed outliers. All the outliers came from samples with low microfossil abundance on which mixed benthic assemblages were dated.

\begin{tabular}{|c|c|c|c|c|c|c|c|c|c|}
\hline No. & Lab ID & $\begin{array}{l}\text { Sample ID } \\
(\mathrm{cm})\end{array}$ & $\begin{array}{r}\text { Depth } \\
(\mathrm{cm})\end{array}$ & $\begin{array}{r}\text { Comp. depth } \\
\text { (year) }\end{array}$ & $\begin{array}{r}{ }^{14} \mathrm{C} \text { age } \\
(\% \circ)\end{array}$ & $\begin{array}{r}\delta^{13} \mathrm{C} \\
(\mathrm{cal} \mathrm{BP})\end{array}$ & $\begin{array}{r}\text { Mean } \\
(\text { cal BP) }\end{array}$ & $1 \sigma$ & $\begin{array}{l}\text { Material } \\
\text { dated }\end{array}$ \\
\hline 1 & 152168 & $6-\mathrm{GC}-2,3-6$ & 44.5 & 44.5 & $1730 \pm 75$ & -0.3 & 850 & $540-1150$ & C. neoteretis \\
\hline 2 & 156282 & $6-\mathrm{GC}-2,70-75$ & 112.5 & 112.5 & $4690 \pm 20$ & 0.98 & 4330 & $3970-4770$ & Mixed benthic \\
\hline 3 & 156283 & 6-GC-2, 93-95, A & 134 & 134 & $6870 \pm 30$ & -0.13 & 6830 & $6510-7190$ & Mixed benthic \\
\hline 4 & 156284 & 6-GC-2, 93-95, B & 134 & 134 & $6400 \pm 25$ & 0.2 & 6330 & $5990-6680$ & N. pachyderma \\
\hline 5 & 152196 & 6-GC-3, 101-105 & 295 & 295 & $8480 \pm 40$ & -0.83 & 8550 & $8180-8920$ & C. neoteretis \\
\hline 6 & 152197 & 6-GC-CC & 494 & 494 & $9030 \pm 35$ & -0.43 & 9180 & $8760-9550$ & C. neoteretis \\
\hline $7 *$ & 156272 & 7-PC-1, 65-72 & 68.5 & 68.5 & $6790 \pm 35$ & -0.67 & 6750 & $6440-7120$ & Mixed benthic \\
\hline 8 & 152208 & 7-PC-1, 103-109 & 106 & 106 & $2670 \pm 20$ & 0.33 & 1850 & $1470-2210$ & Mixed benthic \\
\hline 9 & 156294 & 7-PC-1, 103-115 & 109 & 109 & $2620 \pm 45$ & -0.12 & 1790 & $1410-2130$ & Mixed benthic \\
\hline 10 & 152169 & 7-GC-2, 32-34 & 101 & 140 & $2890 \pm 50$ & -0.62 & 2100 & $1720-2480$ & C. neoteretis \\
\hline 11 & 152198 & 7-TWC-CC & 97 & 164 & $3260 \pm 25$ & -0.73 & 2540 & $2160-2930$ & C. neoteretis \\
\hline 12 & 156309 & 7-PC-2, 23-25 & 175 & 175 & $4060 \pm 30$ & -0.54 & 3540 & $3150-3940$ & Mixed benthic \\
\hline 13 & 152207 & 7-GC-2, 85-87 & 154 & 197 & $5940 \pm 25$ & 1.2 & 5820 & $5520-6190$ & Cibicides lobatulus \\
\hline 14 & 152171 & 7-PC-2, 63-65, A & 215 & 215 & $7090 \pm 70$ & -0.7 & 7050 & $6750-7420$ & C. neoteretis \\
\hline 15 & 153807 & 7-PC-2 63-65, B & 215 & 215 & $6520 \pm 35$ & -0.54 & 6470 & $6140-6830$ & N. pachyderma \\
\hline 16 & 156293 & 7-GC-3, 114-118 & 335 & 415 & $8060 \pm 85$ & -1.62 & 8070 & $7710-8380$ & Mixed benthic \\
\hline $17^{*}$ & 156310 & 7-PC-3, 122-126 & 424 & 424 & $9270 \pm 45$ & -1 & 9500 & $9100-9920$ & Mixed benthic \\
\hline $18^{*}$ & 156308 & 7-GC-3, 125-127 & 345 & 428 & $9350 \pm 45$ & -1.16 & 9610 & $9250-10050$ & Mixed benthic \\
\hline 19 & 152172 & 7-PC-4, 143-145 & 595.5 & 595.5 & $8410 \pm 100$ & -0.91 & 8470 & $8070-8850$ & C. neoteretis \\
\hline 20 & 152170 & 7-GC-CC & 520 & 611 & $8900 \pm 100$ & -1.06 & 9020 & $8630-9430$ & C. neoteretis \\
\hline 21 & 152209 & 7-PC-5, 103-105 & 706.5 & 706.5 & $9460 \pm 45$ & -0.72 & 9750 & 9390-10 170 & C. neoteretis \\
\hline 22 & 152173 & 7-PC-5, 143-145 & 746.5 & 746.5 & $9210 \pm 95$ & -0.72 & 9420 & 9010-9850 & C. neoteretis \\
\hline $23^{*}$ & 156295 & 7-PC-6, 76-78, A & 830.5 & 830.5 & $11000 \pm 160$ & -0.96 & 11850 & $11410-12380$ & Mixed benthic \\
\hline 24 & 152210 & 7-PC-6, 76-78, B & 830.5 & 830.5 & $10200 \pm 40$ & -0.28 & 10730 & $10330-11160$ & C. neoteretis \\
\hline 25 & 154575 & 8-GC-2, 102-104 & 149 & 180 & $3290 \pm 25$ & 1.46 & 2580 & $2200-2970$ & C. neoteretis \\
\hline 26 & 152211 & 8-GC-3, 102-104 & 301 & 341 & $4090 \pm 20$ & N/A & 3580 & $3190-3980$ & C. neoteretis \\
\hline 27 & 156285 & 8-PC-3, 61-63, B & 362.5 & 400.5 & $4480 \pm 20$ & -0.04 & 4070 & $3680-4480$ & C. neoteretis \\
\hline $28 *$ & 156311 & 8-PC-3, 61-63, A & 362.5 & 400.5 & $9280 \pm 35$ & -0.31 & 9520 & $9120-9930$ & Mixed benthic \\
\hline $29 *$ & 156312 & $8-P C-3,63-65$ & 364.5 & 402.5 & $6310 \pm 30$ & 0.32 & 6230 & $5900-6580$ & Mixed benthic \\
\hline 30 & 156288 & $8-P C-3,73-75$ & 374.5 & 412.5 & $5000 \pm 20$ & -1.03 & 4720 & $4370-5170$ & Mixed benthic \\
\hline 31 & 152213 & 8-PC-3, 83-85 & 384.5 & 422.5 & $5260 \pm 30$ & -0.27 & 5040 & $4710-5460$ & C. neoteretis \\
\hline 32 & 152212 & $8-G C-4,62-64$ & 411.5 & 495 & $7220 \pm 40$ & -0.37 & 7190 & $6900-7540$ & C. neoteretis \\
\hline 33 & 152174 & 8-GC-CC & 499 & 609 & $7690 \pm 65$ & -0.85 & 7680 & $7380-8000$ & C. neoteretis \\
\hline 34 & 152298 & 8-PC-5, 46-49 & 648 & 686 & $9140 \pm 40$ & -0.75 & 9330 & $8940-9750$ & C. neoteretis \\
\hline 35 & 156313 & 8-PC-5, 68-72 & 670.5 & 708.5 & $10400 \pm 70$ & -0.62 & 11010 & $10550-11450$ & Mixed benthic \\
\hline 36 & 152279 & 9-TWC-CC & 101 & 201 & $3550 \pm 55$ & -0.31 & 2900 & $2550-3320$ & Mixed benthic \\
\hline 37 & 152300 & 9-PC-4, 103-105 & 556.5 & 556.5 & $4380 \pm 25$ & -0.33 & 3940 & $3560-4350$ & C. neoteretis \\
\hline 38 & 152280 & 9-PC-4, 123-125 & 576.5 & 576.5 & $6620 \pm 65$ & -0.47 & 6570 & $6250-6940$ & C. neoteretis \\
\hline 39 & 152299 & 9-GC-CC & 590 & 650 & $7780 \pm 40$ & -0.5 & 7770 & $7460-8080$ & C. neoteretis \\
\hline 40 & 152281 & $9-P C-6,53-55$ & 810 & 810 & $8370 \pm 110$ & -0.79 & 8420 & $8010-8780$ & C. neoteretis \\
\hline 41 & 156287 & $10-$ GC-1, 50-54 & 50 & 50 & $2450 \pm 20$ & -0.05 & 1600 & $1250-1950$ & Mixed benthic \\
\hline 42 & 152301 & 10-GC-1, 102-104, A & 103 & 103 & $6750 \pm 35$ & -0.6 & 6710 & $6380-7070$ & C. neoteretis \\
\hline 43 & 153806 & 10-GC-1, 102-104, B & 103 & 103 & $6750 \pm 30$ & 0.15 & 6710 & $6390-7070$ & N. pachyderma \\
\hline 44 & 152302 & 10-GC-2, 132-134 & 279.5 & 279.5 & $7880 \pm 45$ & -0.34 & 7880 & $7560-8190$ & C. neoteretis \\
\hline 45 & 152282 & 10-GC-CC, A & 288 & 288 & $8270 \pm 90$ & -0.59 & 8310 & $7910-8640$ & C. neoteretis \\
\hline 46 & 153808 & 10-GC-CC, B & 288 & 288 & $8060 \pm 35$ & -1.61 & 8060 & $7720-8370$ & N. pachyderma \\
\hline 47 & 152303 & $11-G C-1,12-14$ & 13 & 13 & $7540 \pm 30$ & -0.3 & 7520 & $7240-7860$ & C. neoteretis \\
\hline 48 & 152283 & 11-GC-1, 102-104 & 103 & 103 & $11150 \pm 250$ & -0.24 & 12010 & $11580-12610$ & C. neoteretis \\
\hline
\end{tabular}


of laminations indicates somewhat discontinuous deposition with more frequent episodes of erosion near the base of LU5 when deposition occurred closer to the grounding zone. The thinner nature of LU5 at on the shallow inner sill (8-PC, 9$\mathrm{PC})$, and lack of relatively coarse, Ca-enriched laminae like those found near the base of LU5 in 6-GC and 7-PC, indicates a later onset for continuous sedimentation. On the outer sill, the more condensed LU5 in 10-GC also indicates a more dynamic depositional environment likely influenced by current activity or ice scouring.

LU4. Faint, planar millimeter-scale laminations that lack notable evidence for bioturbation define LU4. The transition between LU5 and LU4 is gradual, with the base of LU4 being identified by a notable and correlative decline in $\mathrm{Ca}$ abundance that is identified at all the coring stations (Fig. 5). Laminations in LU4 are only weakly visible with the naked eye but are evident in the CT scanning data (Fig. 7). In 7$\mathrm{PC}$ and 6-GC, laminations appear to transition from wavy to lenticular with frequent faulting in LU5 to planar in LU4. With the exception of 10-GC on the outer sill, coarse icerafted clasts remain dispersed in low numbers through LU4. LU4 is a silty clay containing very minor amounts of sand $(<1 \%)$, with some samples showing a slight elevation of medium to coarse silt (Fig. 8). The bulk density remains relatively constant $\left(1.6-1.8 \mathrm{~g} / \mathrm{cm}^{3}\right)$ with mass-specific magnetic susceptibility higher than in LU5 and increasing up-core towards the top of the unit, consistent with a continued up-core decrease in detrital carbonate concentrations. Occasional minor pulses of $\mathrm{Ca}$ are seen throughout the unit. The LU5 to LU4 transition appears correlative across the fjord, and many small-scale features in the $\mathrm{Ca}$, bulk density, and magnetic susceptibility logs can be traced between the sites (Fig. 5).

We interpret LU4 as laminated-meltwater-influenced sediments dominated by suspension settling in an ice distal environment. This is consistent with the gradual transition seen between LU5 and LU4. The apparent correlative nature of LU4 across the fjord suggests uniform and continuous deposition.

LU3. Throughout Sherard Osborn Fjord, LU4 is capped by LU3, a second diamicton containing large gravel to cobblesized clasts (Figs. 6 and 7). LU3 is recognized by its high bulk density $\left(1.8-2.0 \mathrm{~g} / \mathrm{cm}^{3}\right)$, elevated Ca-content, and abundant clast content (Fig. 5). LU3 has a low-mass-specific magnetic susceptibility except at 8-PC from which cobble and bolder sized clasts of felsic rocks were recovered, which presumably led to the high susceptibility measurements. CT images from 6-GC and 7-PC show that the lower boundary is heavily bioturbated, while at 8-PC and 9-PC it is marked by a higher concentration of coarse clasts that tend to fine upwards (Fig. 7). At 8-PC the coarse clasts appear to have been smeared down the inside of the core liner, artificially increasing the clast content of the underlying LU4. In all cores, the lower boundary of LU3 and uppermost $5-10 \mathrm{~cm}$ of LU4 are bioturbated. The upper boundary of LU3 is relatively sharp at all sites. The matrix material of LU3 is clayey silt with a generally coarser mean grain size compared to LU4 and a larger sand-sized contribution (up to $4.5 \%$ ) (Fig. 8). The only indication of deformation is seen in 8-PC surrounding the region where large dropstones were recovered. The absence of deformation at the other sites suggests that this is an artifact of coring and not a primary depositional feature. We interpret LU3 as a glaciomarine diamicton, primarily composed of ice-rafted material deposited by icebergs and sea ice.

LU2. A sharp but bioturbated boundary separates LU3 from LU2 at all sites except $10-\mathrm{GC}$ on the outer sill. The defining characteristic of LU2 is the presence of bioturbation and lack of preserved laminations. This unit exhibits very little variation in the bulk density or Ca content (Fig. 5), is composed primarily of fine silt and clay, and contains very few scattered ice-rafted clasts (Fig. 7). The thickness of LU2 varies considerably across the fjord, with the thickest occurrences in 6-GC and 7-PC. LU2 is nearly absent in sediments from the outer sill (10-GC) where there is an abrupt and nonbioturbated contact between LU3 and LU2 (Fig. 5).

$L U 1$. A return to a laminated facies lacking coarse icerafted clasts and bioturbation defines LU1. The grain size spectra of LU1 closely resemble those from LU4 (Fig. 8). The laminations in LU1 are also highly fractured and distorted along the sides of the core. This is attributed to coring disturbance and the soft nature of these near-surface sediments. LU1 is divided into two subunits. LU1b is only found at stations 8 and 9 on the inner sill. It is a faintly laminated unit with some discrete intervals where the laminations are disturbed, sometimes by bioturbation. LU1b has low abundances of $\mathrm{Ca}$, similar to what is found in LU2 and LU4 (Fig. 5). LU1a is marked by the emergence of more pronounced millimeter- to centimeter-scale laminations that are only seen clearly in the CT images (Fig. 7). LU1a is marked by increased $\mathrm{Ca}$ concentrations which are most apparent in 9-PC and 7-PC (Fig. 4). At stations 10, 6, and 7, LU1a sits abruptly on top of LU2 (Fig. 5), while at stations 8 and 9, there is a gradual transition between LU1b and LU1a.

\subsection{Ages of unit boundaries}

Radiocarbon dating is used to constrain the ages of lithostratigraphic unit and subunit boundaries. In most cases samples were collected from within a few centimeters of these boundaries in one or more cores (Fig. 5). The youngest age underlying a unit or subunit boundary is used to provide a maximum age for the boundary (Fig. 9). However, this is not possible for the LU5-LU6 and LU1b-LU2 boundaries. For LU6 the oldest age from the overlying unit is adopted as the minimum boundary age. A younger than and older than age is provided for LU1b, based upon dates obtained from two different cores (Table 4). Of the 48 radiocarbon dates, 7 were identified as outliers because the underlying ages are younger and fell outside the $1 \sigma$ calibrated age range. The lowermost sample in 8-PC (Sample \#35, Table 3) is also considered an outlier due to the substantially younger age returned in a sam- 

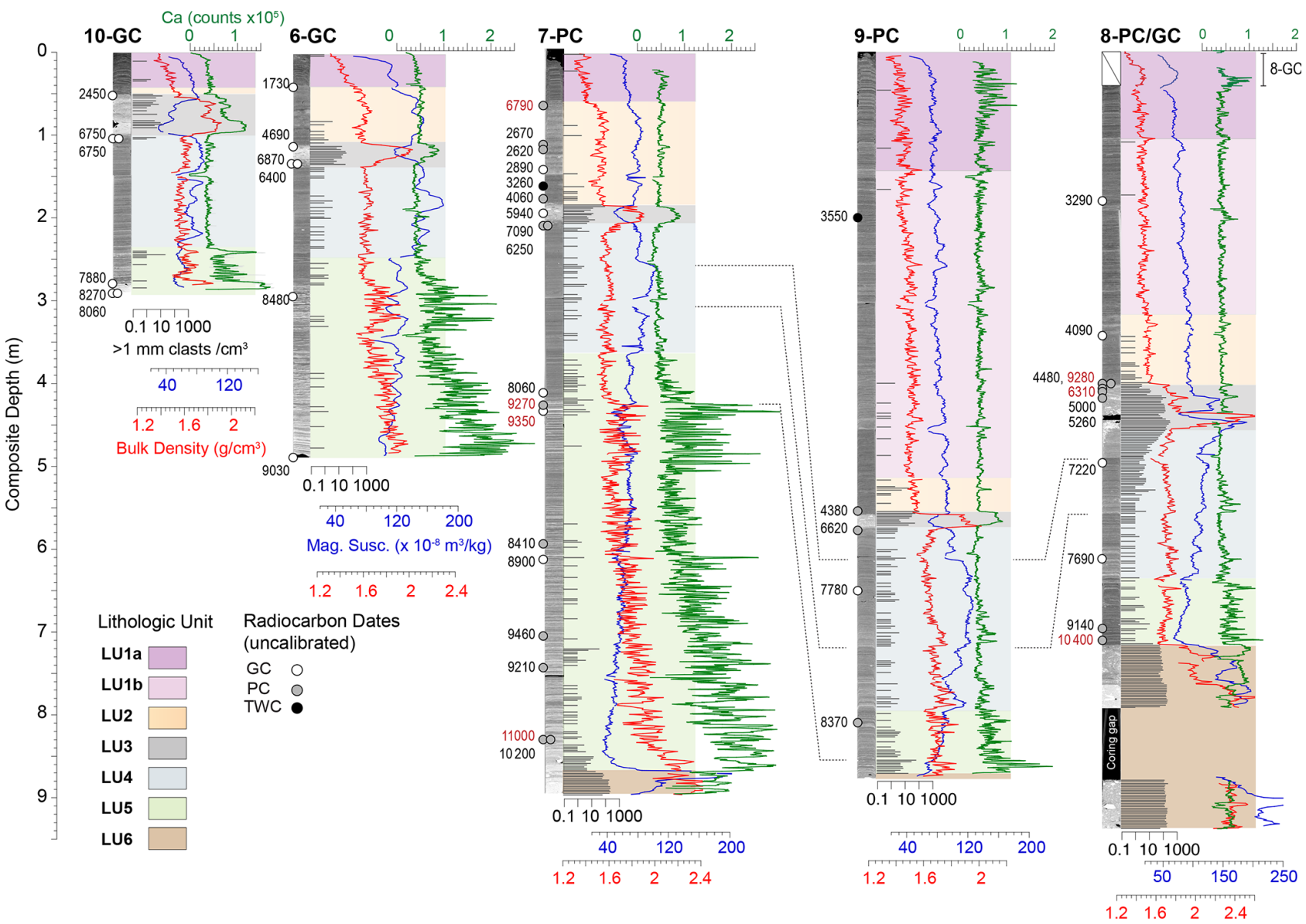

Figure 5. Summary of stratigraphy and correlation of lithologic units between coring stations in Sherard Osborn Fjord. Locations and uncalibrated ages of radiocarbon dates are shown. Key horizons in LU5 and LU4 that can be correlated between 7-PC, 8-PC, and 9-PC are illustrated by thin black lines. Depths for lithologic unit boundaries are provided for each coring station in the Supplement.

ple $22.5 \mathrm{~cm}$ up-core (Sample \#34, Table 3), and the fact that it was obtained on a mixed benthic assemblage. On the other hand, LU5 sediments from this site were not deposited continuously, implying periods of erosion or non-deposition that could account for the large difference in ages between the lowermost dates in 8-PC (Fig. 9). In any case, due to the general uncertainty about the accuracy of this date, we have decided to treat it as an outlier.

The lithologic sequence from Sherard Osborn Fjord sediments spans nearly the entire Holocene (Table 4), with the oldest boundary (LU5/LU6) dated in 7-PC (Sample \#24) to $10200 \pm 40{ }^{14} \mathrm{C}$ years $(10330-11160 \mathrm{cal} \mathrm{BP})$, while the youngest boundary (LU1a/2) is dated in 6-GC (Sample \#l) to $1730 \pm 40{ }^{14} \mathrm{C}$ years $(540-1150 \mathrm{cal} \mathrm{BP})$. The oldest age comes from 11-GC (Sample \#48, $11150 \pm 250{ }^{14} \mathrm{C}$ years) and provides a constraint on the timing for ice retreat from the outer sill.

The transition between LU3 and LU2 in 10-GC is more abrupt than in other cores and is not bioturbated (Fig. S8). We infer a hiatus across this transition and do not use the younger age (Sample \#41, Table 3) to date this boundary. Instead we rely on the numerous other older dates obtained from the base of LU2 to date this boundary (Fig. 9). Similarly, based on the occurrence of truncated laminae seen clearly in the CT images, frequent intervals of erosion are indicated during deposition of LU5 (Fig. 9). Examples of this in 7-PC, 8-PC, and 9-PC are provided in Fig. S9.

\section{Discussion}

\subsection{Overview of the Holocene lithostratigraphic succession}

The succession of stratigraphic units recovered in Sherard Osborn Fjord mirrors the classic deglacial facies transitions described from ice-shelf settings of Antarctica (Smith et al., 2019) and high-latitude Northern Hemisphere fjords occupied by marine-terminating outlet glaciers and floating ice tongues (O'Cofaigh and Dowdeswell, 2001; Reilly et al., 2019) (Fig. 10). The interpretations of the stratigraphic units are here used to reconstruct Ryder Glacier's dynamical his- 

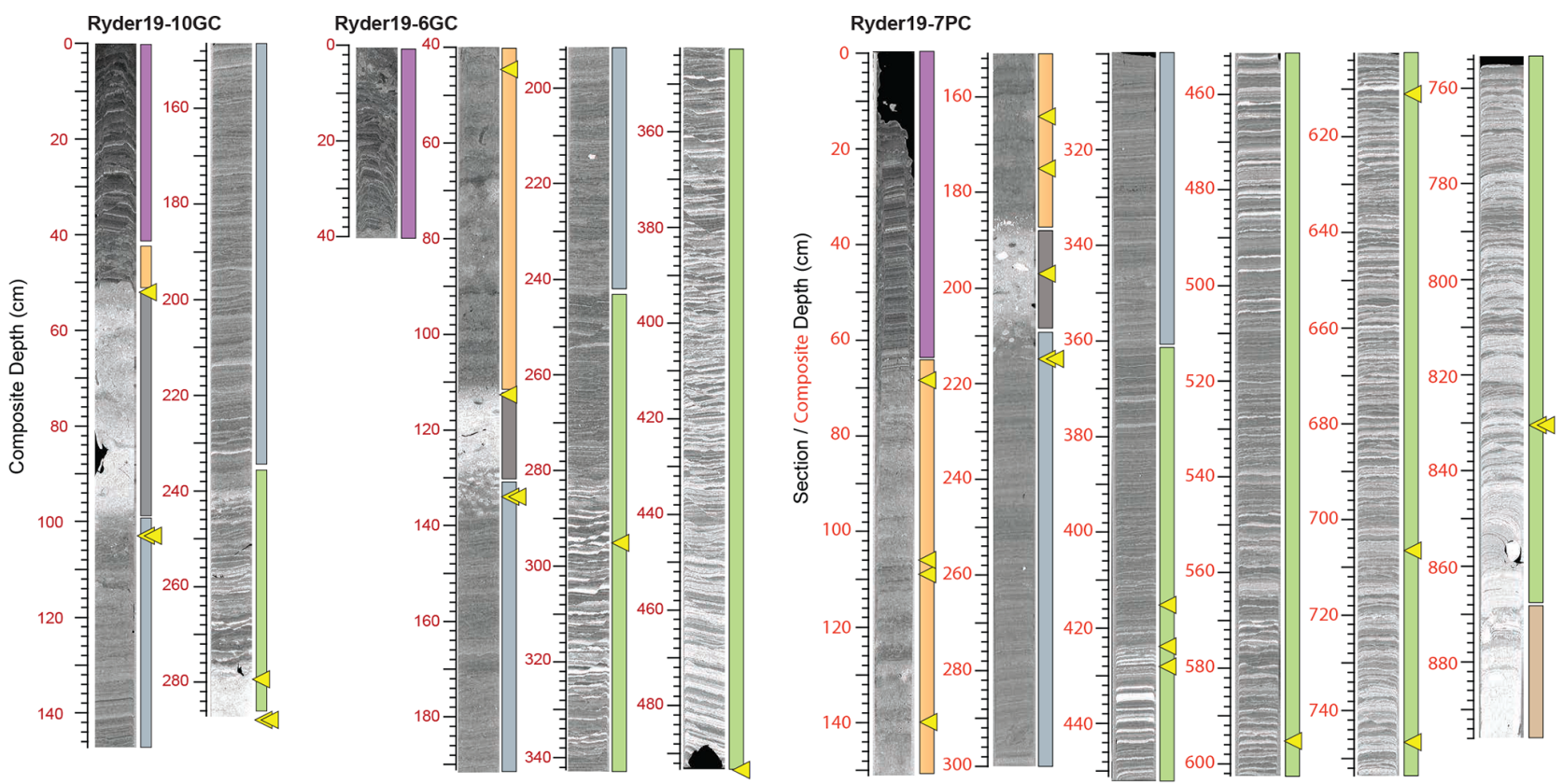

Lithologic Unit
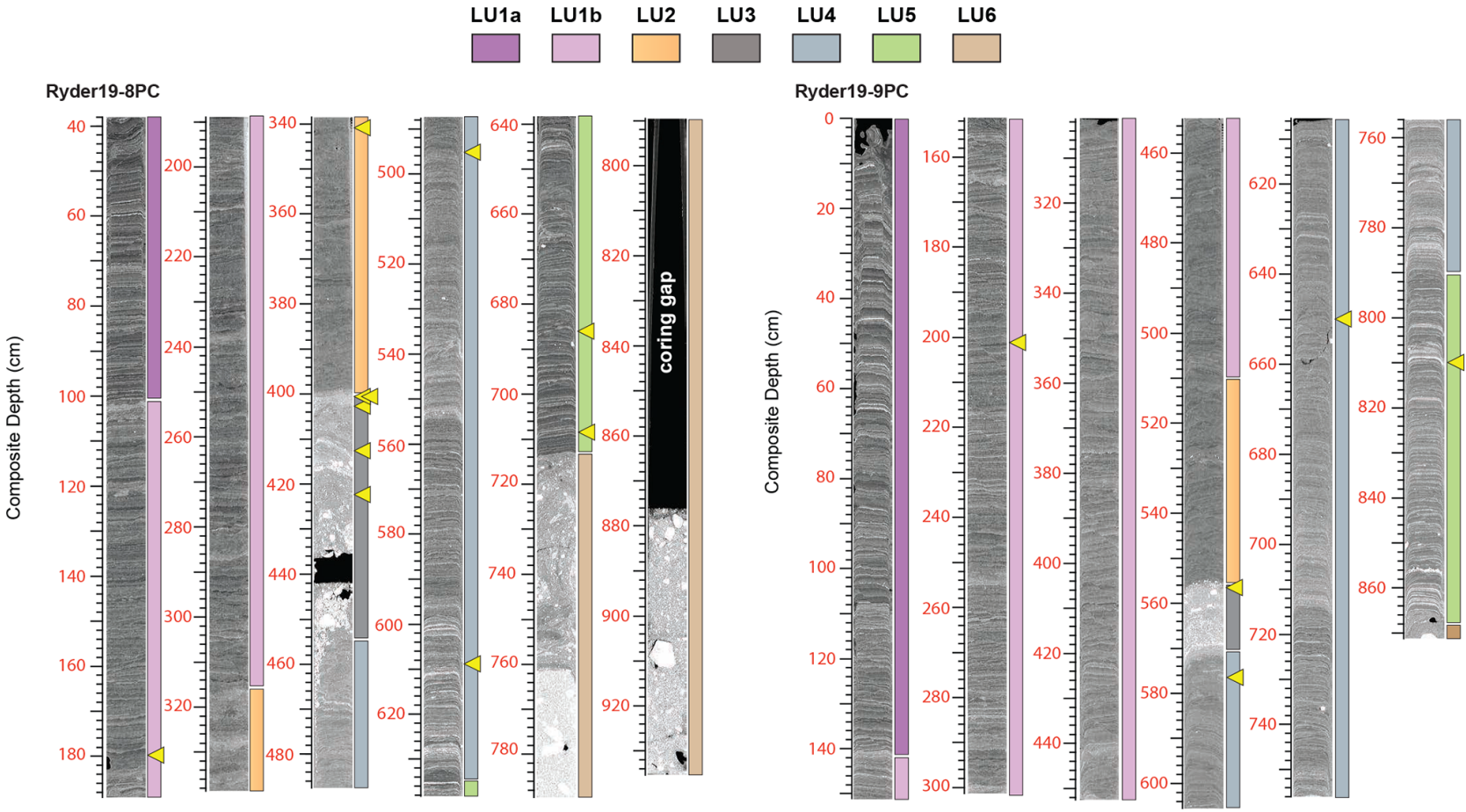

Figure 6. CT images and associated lithologic units for each core. White in CT images corresponds to higher density zones and black to lower density zones. Yellow triangles represent levels of radiocarbon dates. Larger images showing section depths and composite depths are provided in Figs. S2-S6.

tory (Fig. 11). The Sherard Osborn Fjord sequence involves a basal subglacial to glaciomarine diamicton (LU6) overlain by a laminated meltwater-dominated facies. The laminated facies fines upwards from a grounding zone proximal deposit with evidence for traction current activity (LU5) to a ground- ing zone distal facies deposited by suspension settling (LU4) beneath a floating ice tongue (Fig. 9).

The laminated grounding zone distal facies (LU4) is abruptly terminated by a clast-rich diamicton (LU3). Similar facies transitions have been described as a response to migration of the ice shelf calving front, glacier surging or advance, 

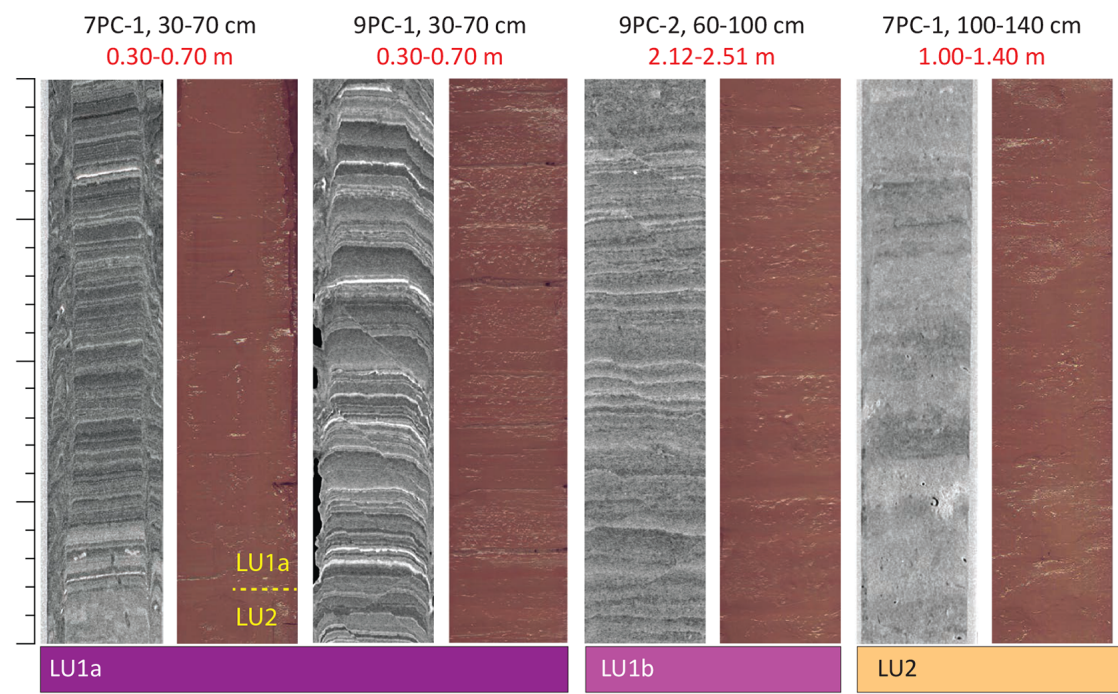

$8 \mathrm{PC}-2,108-148 \mathrm{~cm}$
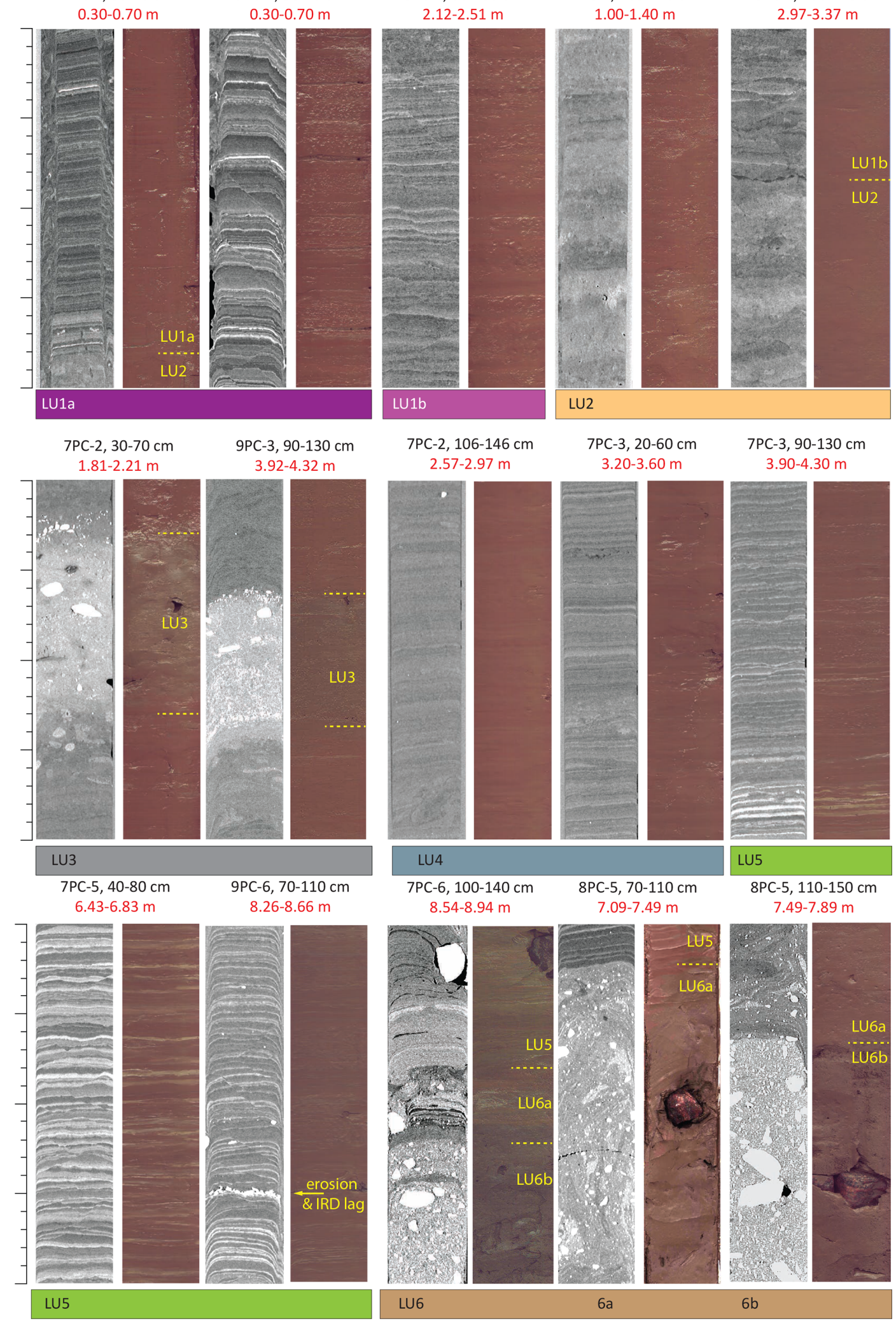

Figure 7. Examples of CT images and color photographs representative of the six lithologic units. The vertical scale for each image is a constant $50 \mathrm{~cm}$. The structures seen on the CT images and the color photographs are not identical because the imaging planes are slightly different. The CT images are representative 2-dimensional slices of the core interior, whereas the photos show the surface of split cores. White in CT images corresponds to higher density zones and black to lower density zones. Composite depths for each interval are given in red. 
Table 4. Key radiocarbon dates and calibrated ranges defining basal ages of lithologic (sub-)unit boundaries. Calibrated ages and uncertainty are rounded to 100 years, with the mean age from the calibrated age range reported. The first column refers to the radiocarbon date index number from Table 3.

\begin{tabular}{lllll}
\hline No. & Sample & Unit & ${ }^{14} \mathrm{C}$ age (year) & Age (cal ka BP) \\
\hline 1 & 06-GC-2, 3-6 cm & 1a & $1730 \pm 75$ & $0.9 \pm 0.3$ \\
36 & 9-TWC-CC & 1b & $>3550 \pm 55$ & $2.9 \pm 0.4$ \\
26 & 8-GC-3, 102-104 & 1b & $<4090 \pm 20$ & $3.6 \pm 0.4$ \\
37 & 9-PC-4, 103-105 cm & 2 & $4380 \pm 25$ & $3.9 \pm 0.4$ \\
4 & 06-GC-2, 93-95 cm, B & 3 & $6400 \pm 25$ & $6.3 \pm 0.3$ \\
44 & 10-GC-2, 132-134 cm & 4 & $7880 \pm 45$ & $7.9 \pm 0.3$ \\
24 & 7-PC-6, 76-78 cm, B & 5 (mid-fjord) & $10200 \pm 40$ & $10.7 \pm 0.4$ \\
34 & 8-PC-5, 46-49 cm & 5 (inner sill) & $9140 \pm 40$ & $9.3 \pm 0.4$ \\
\hline
\end{tabular}

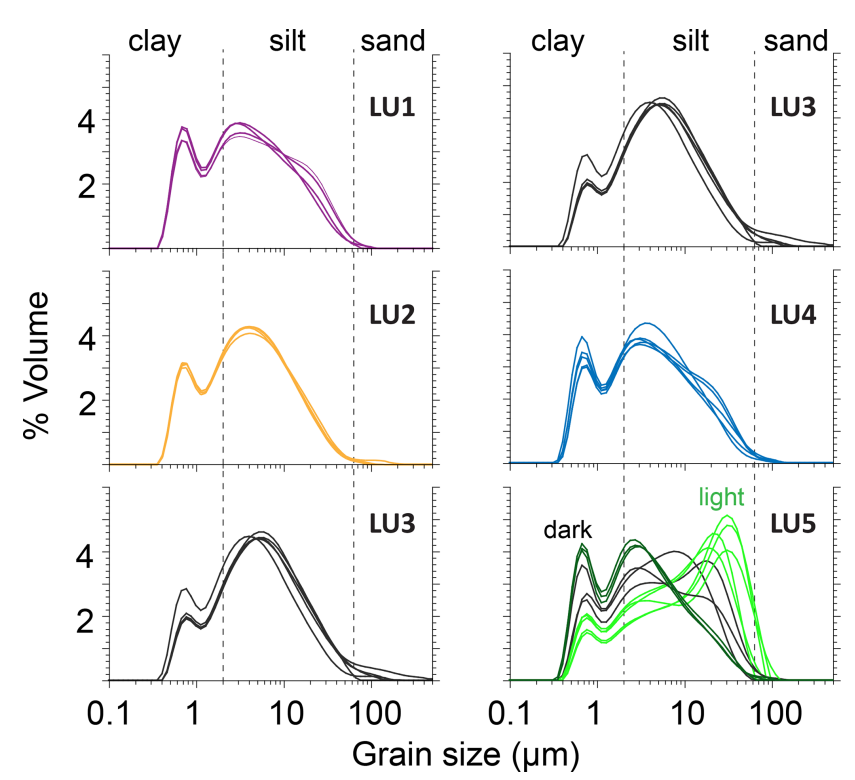

Figure 8. Grain-sized spectra of lithologic units 1-5 illustrating the similar grain size distributions of sediments in LU1 and LU4, as well as the difference between the dark (less dense) and light (more dense) laminations in LU5.

or ice shelf collapse (Smith et al., 2019). In Sherard Osborn Fjord, the overlying sediments (LU2) are clast poor with extensive bioturbation suggesting deposition under more productive surface waters indicative of less extensive surface ice cover. As such, the facies succession, with LU3 separating the grounding zone distal (LU4) and more open-water bioturbated sediments (LU2), is consistent with a collapse of Ryder's ice tongue. The removal of an ice tongue marking the onset of LU3 allowed enhanced input of poorly sorted icerafted material as debris-laden icebergs calved directly from the grounding zone and were able to traverse the fjord. A return to a laminated facies (LU1), similar in character to LU4, indicates the successive re-establishment of an ice tongue that eventually extended to the outer sill in Sherard Osborn Fjord. This interpretation is supported by historical observa- tions of Lauge Koch, who mapped the ice-tongue limit in proximity to the outer sill in 1917 (Koch, 1928) (Fig. 2).

\subsection{Early Holocene glacier and ice tongue dynamics}

The oldest recovered sediments come from 11-GC on the outer sill where a sample of the benthic foraminifera Cassidulina neoteretis returned a date of $12 \pm 0.5 \mathrm{ka}$ cal BP. Due to the limited amount of sediment that has accumulated above the bedrock/till at 6-GC, 10-GC and 11-GC (Fig. 4), we interpret this as a minimum age for the retreat of Ryder Glacier from the outer sill, where it was grounded 80$90 \mathrm{~km}$ seaward from its current position (Fig. 11). Deposition of the grounding zone proximal meltwater sediments (LU5) above a likely subglacial diamicton in 7-PC commenced at $10.7 \pm 0.4 \mathrm{kacal} \mathrm{BP}$, indicating that the glacier had retreated further inland by this time (Fig. 10). The calibrated ranges of radiocarbon dates from the base of 7-PC (10.3-11.1 ka cal BP) conform to the reported age for the Kap Fulford Stade (> 10.5 ka cal BP) (Kelly and Bennike, 1992) (Fig. 11). It is less certain if the older age from $11-\mathrm{GC}$ on the outer sill (11.6-12.6 ka cal BP) (Fig. 9, Table 3) implies that grounded ice was here during the Kap Fulford Stade or an earlier stage of deglaciation.

Following the retreat of Kap Fulford glacial ice, the sedimentary sequence is dominated by the Ca-rich laminated meltwater facies (LU5). The coarser-grained Ca-enriched laminae are associated with increased meltwater input from glacial erosion of the surrounding Cambrian and Silurian carbonate shelf bedrock (Fig. 2). The strong meltwater signal captured in LU5 coincides with the rapid Early Holocene reduction in the height of the GrIS (Lecavalier et al., 2017) (Fig. 10).

Sediments from LU5 are comparatively thin at the inner sill coring sites and difficult to directly correlate with the records from 6-GC and 7-PC. Erosional events identified in LU5 sediments from the inner sill suggest discontinuous sedimentation (see 9PC-6, Figs. 7 and S9). Sitting in much shallower water depths (228-271 mb.s.l.; Table 1), glacial ice likely remained grounded here after it retreated from sta- 


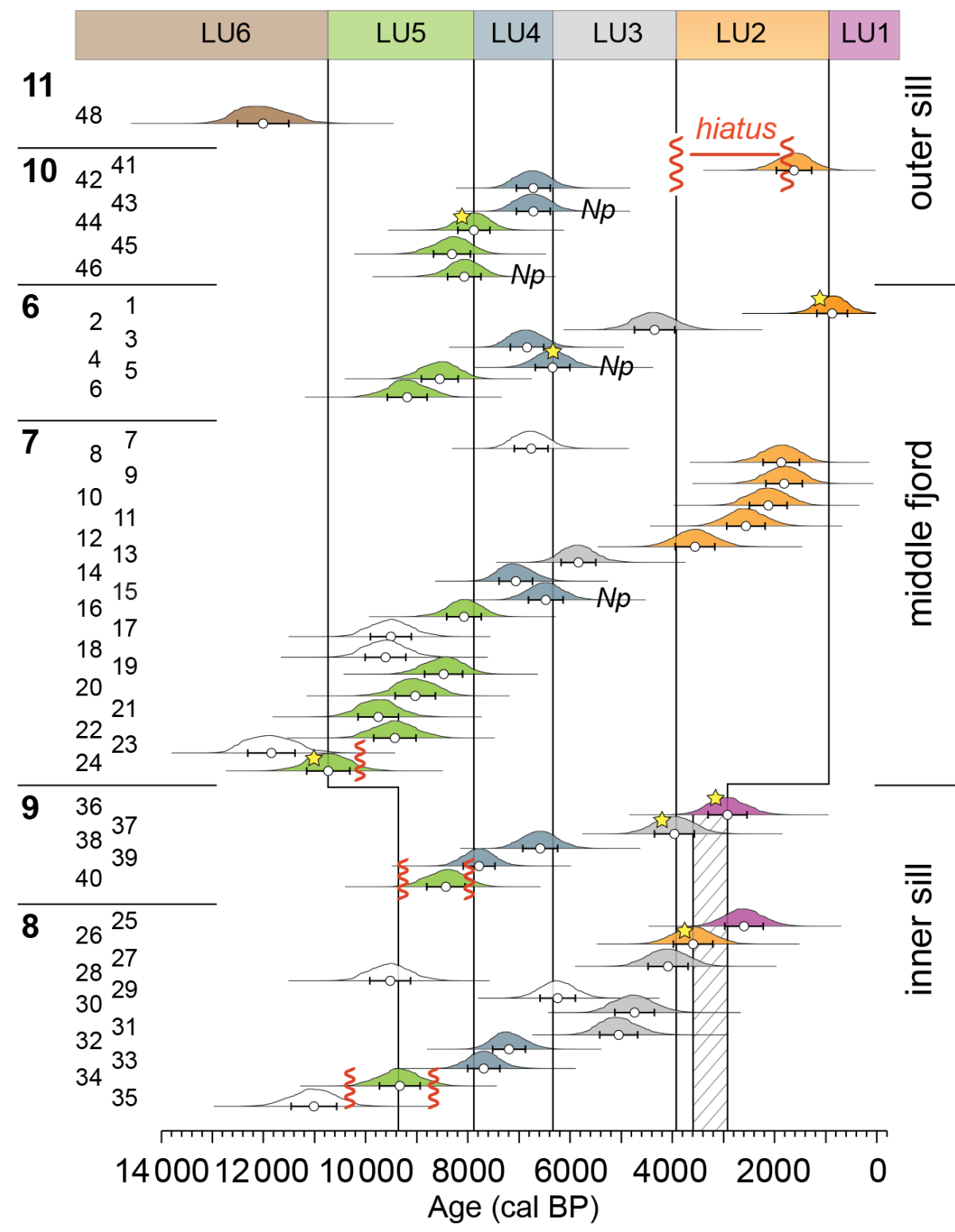

Figure 9. Likelihood distributions of calibrated radiocarbon dates illustrating the mean and $1 \sigma$ age ranges. Color-coding is used to identify the lithologic unit that each date was acquired from. Dates from each core are presented in their stratigraphic order. White indicates ages that are deemed to be outliers. Yellow stars indicate dates used to define the ages of unit boundaries (Table 4). On the inner sill, the age range for the LU2-LU1b transition is bracketed by an "older than" and "less than" age from 9-PC and 8-PC respectively. Index numbers correspond to those in Tables 3 and 4. Date \#47 from 11-GC is not shown as it could not be definitively placed within a lithologic unit. $N p$ indicates date obtained on N. pachyderma.

tions 6 and 7. Deposition on the inner sill would also have been influenced by bottom scouring currents and debris flows while the glacier was grounded (or near flotation) on shallow regions of the sill that rise to depths of $193 \mathrm{~m}$. Therefore, we suggest that Ryder Glacier remained grounded on or near the inner sill until sometime after $9.3 \pm 0.4 \mathrm{ka}$ cal BP, which marks the onset of continuous sedimentation of LU5 at this location (Fig. 11; Table 4). This is consistent with the age of the Warming Land Stade, bracketed between $>9.5$ and
8.0 ka cal BP by Kelly and Bennike (1992). The shallow inner sill, first identified through bathymetric mapping during the Ryder 2019 expedition (Jakobsson et al., 2020), is very close to the previously inferred grounding zone location for the Warming Land Stade and provides a natural pinning point for the marine-based glacier during this standstill (Fig. 2).

In 6-GC and 7-PC there is a broad period of elevated detrital carbonate delivery (high Ca-content) that occurs near the top of LU5 (Fig. 5). This likely reflects enhanced melt- 


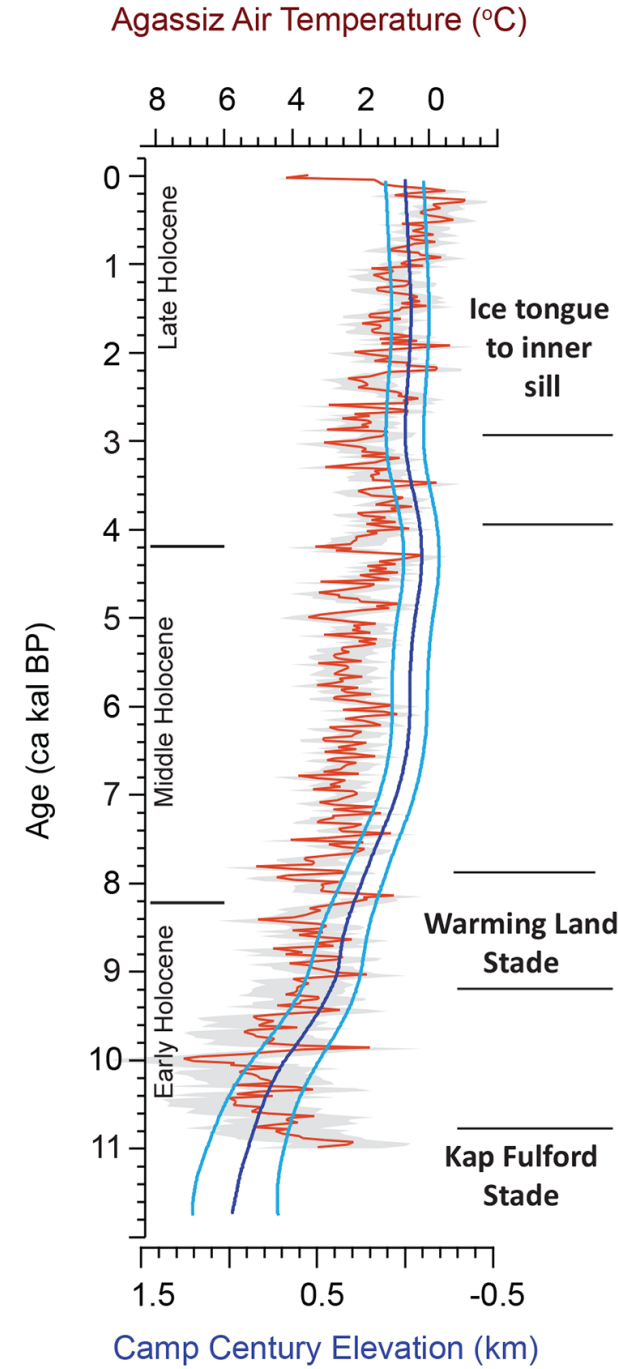

Agassiz Air Temperature $\left({ }^{\circ} \mathrm{C}\right)$

Camp Century Elevation $(\mathrm{km})$
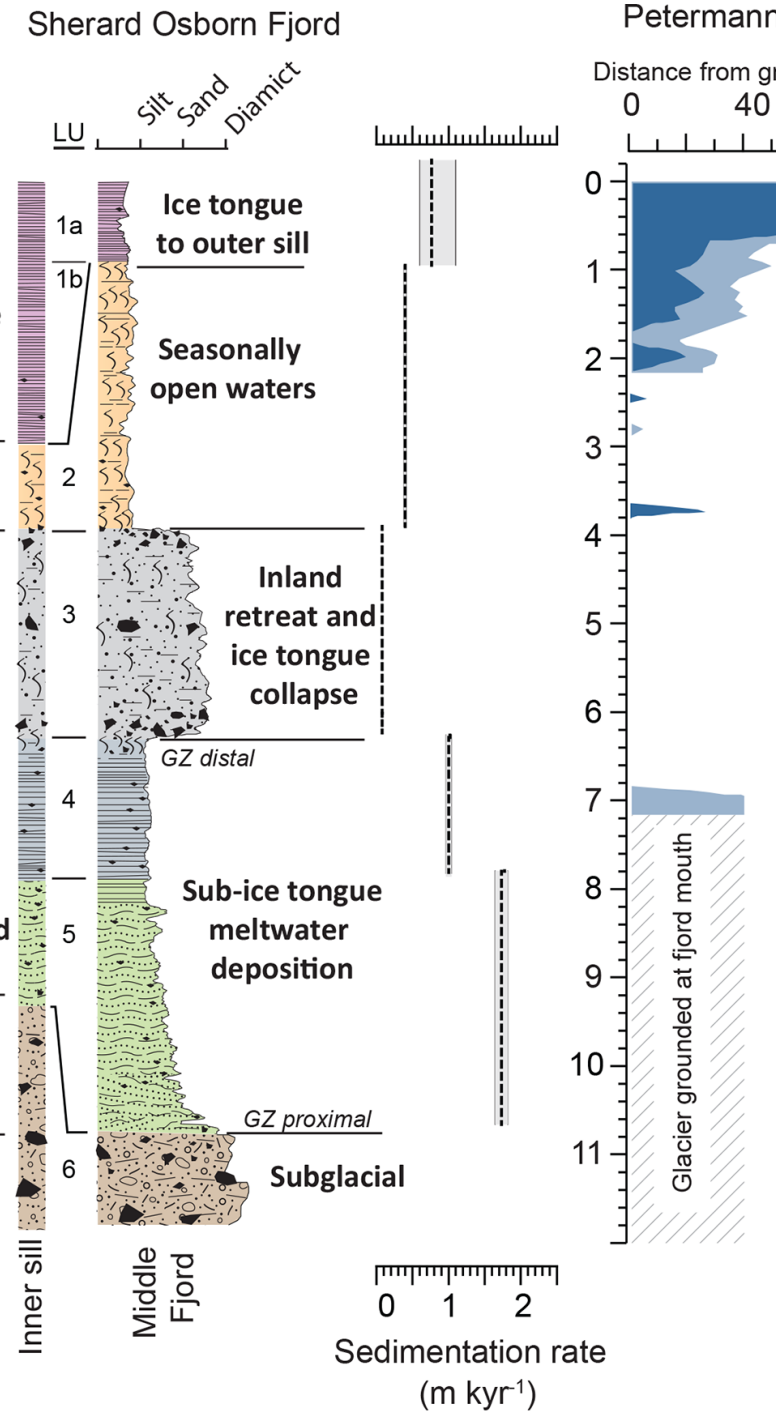

Permann ice tongue
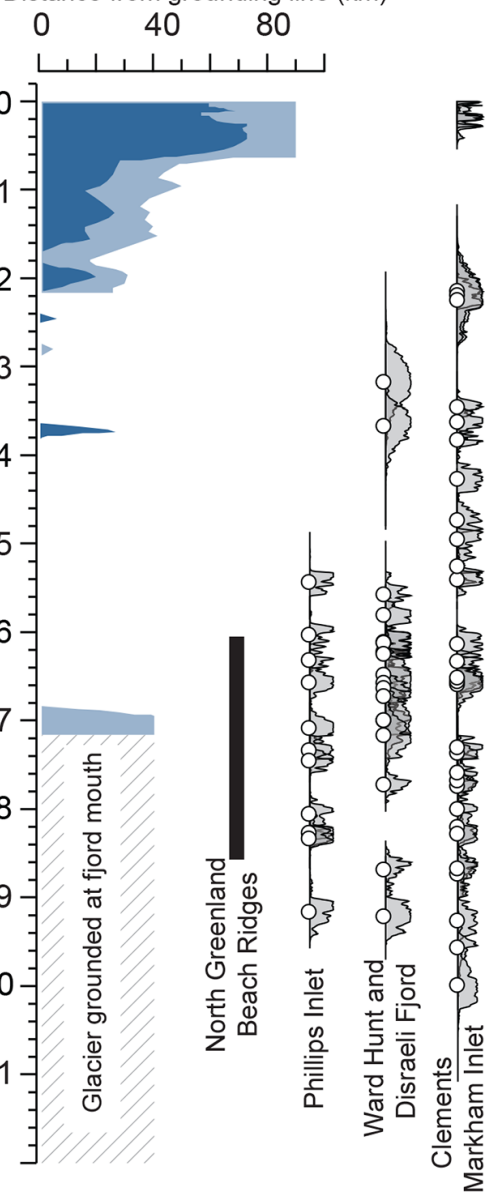

Ellesmere Island
Drift wood

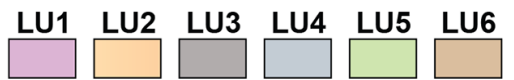

Figure 10. Representative lithostratigraphic column and environmental interpretations for the sedimentary cover of the inner sill and middle fjord. Approximate linear sedimentation rates are provided for the middle fjord (station 7, Fig. 2) using the derived unit boundary ages and their uncertainty (Table 3). The interpreted lithostratigraphic column is shown alongside the Agassiz air temperature reconstruction and elevation changes in the GrIS at Camp Century (Lecavalier et al., 2017); the reconstructed extent of Petermann Glacier ice tongue (Reilly et al., 2019); the period of beach ridge formation along the north coast of Greenland indicating the absence of perennial landfast ice (Möller et al., 2010); and driftwood delivery to northern Ellesmere Island (England et al., 2008). Radiocarbon dates from England et al. (2008) were recalibrated using Intcal20.

water delivery during terrestrial ice retreat at the end of the Warming Land Stade prior to the LU4/LU5 boundary at $7.6 \pm 0.40 \mathrm{kacal} \mathrm{BP}$ (Fig. 11; Table 4). Across Sherard Osborn Fjord, deposition of the laminated LU4 sediments continued until $6.3 \pm 0.3 \mathrm{kacal} \mathrm{BP}$ (Fig. 11; Table 4), which is very similar to the age $(6.0 \mathrm{kacal} \mathrm{BP})$ for the minimum Holocene extent reported for Ryder Glacier (Kelly and Bennike, 1992).

\subsection{Middle Holocene inland retreat and collapse of Ryder's ice tongue}

The second diamict facies (LU3) in the stratigraphic succession separates the faintly laminated sub-ice-tongue sediments of LU4 and the bioturbated facies of LU2. As this unit is found from the inner sill all the way to the outer sill and does not appear to be time-transgressive, it cannot be attributed to a slow landward migration of the ice tongue calving mar- 
gin. Instead, it is interpreted as a collapse facies (Smith et al., 2019) associated with the sudden disintegration of Ryder's ice tongue. While this interpretation fits with the overall facies succession, the $\sim 2.4$ kyr duration of LU3 (from $6.3 \pm 0.3$ to $3.9 \pm 0.4 \mathrm{ka}$ cal BP; Table 4 ) is too long to be a simple abrupt collapse event as these are generally associated with increased sediment accumulation rates (Smith et al., 2019).

An alternate interpretation is that LU3 sediments represent an erosional event. However, this does not fit with the overlapping ages of sediments from the top of LU4 at coring stations $6,7,9$, and 10, and to a large degree the ascending ages found downcore through LU3 at station 8 (Fig. 9). Therefore, the widespread distribution, long duration, and consistent boundary ages of LU3 and lack of evidence for pervasive ice scouring make it hard to reconcile this facies with a glacial surge. This unit is also much younger than the inferred age for the drainage of the ice dammed lake that developed on Wulff Land between Ryder and C. H. Ostenfeld glaciers between 7.9-8.5 ka cal BP (Kelly and Bennike, 1992). These observations suggest that LU3 marks a period of low sedimentation that began around $6.3 \pm 0.3 \mathrm{ka} \mathrm{cal} \mathrm{BP}$ when terrestrial studies suggest that Ryder Glacier had retreated further inland than its current position (Kelly and Bennike, 1992), similar to much of the ice margin along northwestern Greenland during the Middle and Late Holocene (Søndergaard et al., 2020).

In Sherard Osborn Fjord, a relatively deep, isolated marine embayment exists behind a prominent topographic high lying $40 \mathrm{~km}$ inland of the modern grounding zone (Fig. 12). Here elevations increase to between $100-200 \mathrm{~m}$ above sea level, with elevations surrounding the embayment reaching 400-600 m above sea level (Figs. 11 and 12). Retreat of the grounding zone onto this topographic high (possibly a former grounding zone wedge), or even inland of it, would explain the apparent rapid disintegration of the ice shelf at the end of LU4. The entrainment of meltwater-derived sediments within the isolated embayment or even behind the inner sill can account for the overall reduction in sedimentation rates in the outer fjord. This is consistent with observations from modern proglacial lakes that illustrate their efficiency at disrupting meltwater fluxes and sequestering sediments (Carrivick and Tweed, 2013; Bogen et al., 2015; Piret et al., 2021). While grounded in this distal position, calving could have discharged some icebergs into Sherard Osborn Fjord, delivering coarse-grained ice-rafted sediments. Elevated Ca contents within LU3 (Fig. 5) attest to sediment provenance being primarily landward of the inner sill (Fig. 2). Furthermore, the sedimentation rates during LU3 are low $(9-10 \mathrm{~cm} / \mathrm{kyr}$; Fig. 10) and comparable with sedimentation rates of 10 $30 \mathrm{~cm} / \mathrm{kyr}$ reported by Dowdeswell et al. (1994) for massive diamicts derived from iceberg rafting in Scoresby Sund and the adjacent east Greenland shelf. A final indication that Ryder Glacier retreated to the innermost fjord or beyond is the lack of iceberg scouring seen in bathymetric data on the in- ner sill. This suggests that the calving front was grounded in water shallow enough to not produce icebergs in excess of 190-200 m thickness - a condition that can easily be met by the landward retreat of Ryder Glacier (Fig. 11).

A modern analogue for this configuration is seen in neighboring Victoria Fjord. Today C. H. Ostenfeld Glacier is grounded on a topographic high at the end of the fjord in an equivalent position to the landward terminus of Sherard Osborn Fjord where the proposed Middle Holocene ice margin is located (Fig. 11). Between 2000-2006, the C. H. Ostenfeld ice tongue, which protruded from a narrow over-deepened marine channel, largely disintegrated (Moon and Joughin, 2008), while the grounding zone may soon become increasingly land-based and discharge grounded ice directly into Victoria Fjord (Hill et al., 2017) (Fig. 11).

The retreat of Ryder Glacier through the Early and Middle Holocene is consistent with many regional paleoclimate proxies from around northern Greenland. This includes beach ridge formation along the north Greenland coast, indicating more open water conditions that persisted until $\sim 6 \mathrm{kacalBP}$ (Möller et al., 2010; Funder et al., 2011a), reduced winter sea-ice conditions in Bliss Lake until $6.5 \mathrm{ka} \mathrm{cal} \mathrm{BP}$ (Olsen et al., 2012), and peak late summer air temperatures inferred from $\delta^{18} \mathrm{O}$ of chironomids in Secret and Deltas $\varnothing$ lakes that were $>2{ }^{\circ} \mathrm{C}$ warmer then present until $6.2 \mathrm{ka}$ cal BP (Axford et al., 2019; Lasher et al., 2017) (Fig. 1). The paleotemperature estimates from these lakes indicate a slight cooling but persistent, stable, and positive temperatures between $\sim 6.0-4.0 \mathrm{kacal}$ BP (Lasher et al., 2017; McFarlin et al., 2018). Diminished sediment delivery due to the presumably stable inland position of Ryder Glacier lasted from $6.3 \pm 0.3$ to $3.9 \pm 0.4 \mathrm{kacalBP}$ (Table 4). The inferred re-advance into Sherard Osborn Fjord, marked by increased sediment delivery at the onset of LU2, occurred around $3.9 \pm 0.4 \mathrm{kacal} \mathrm{BP}$. This timing for glacier advance is consistent with cooling seen in lake-based temperature reconstructions around $4 \mathrm{ka} \mathrm{cal} \mathrm{BP}$ (Lasher et al., 2017) and the oldest estimated age ( 3.5 to $4.0 \mathrm{kacal} \mathrm{BP}$ ) for ice at the base of the southern dome of Hans Tausen ice cap, which had disappeared during the Middle Holocene - although northern parts of the ice cap survived (Madsen and Thorsteinsson, 2001; Landvik et al., 2001; Zekollari et al., 2017). However, it should be emphasized that the onset of deposition of LU2 at $3.9 \pm 0.4 \mathrm{ka}$ cal BP marks the advance of Ryder Glacier into Sherard Osborn Fjord, while terrestrial-based ice may have started advancing earlier.

A stable inland position for Ryder Glacier during LU3 fits with generally colder conditions that prevailed over north Greenland towards the end of the Middle Holocene. This is reflected in the development of more prolonged winter ice cover in Bliss Lake after $5.9 \mathrm{ka}$ cal BP (Olsen et al., 2012) and a period of low melt rates for the north GrIS inferred from elevation changes at Camp Century (Lecavalier et al., 2017) (Fig. 10). Therefore the prolonged slow deposition of coarse IRD during LU3 is likely a combined effect of limited but 


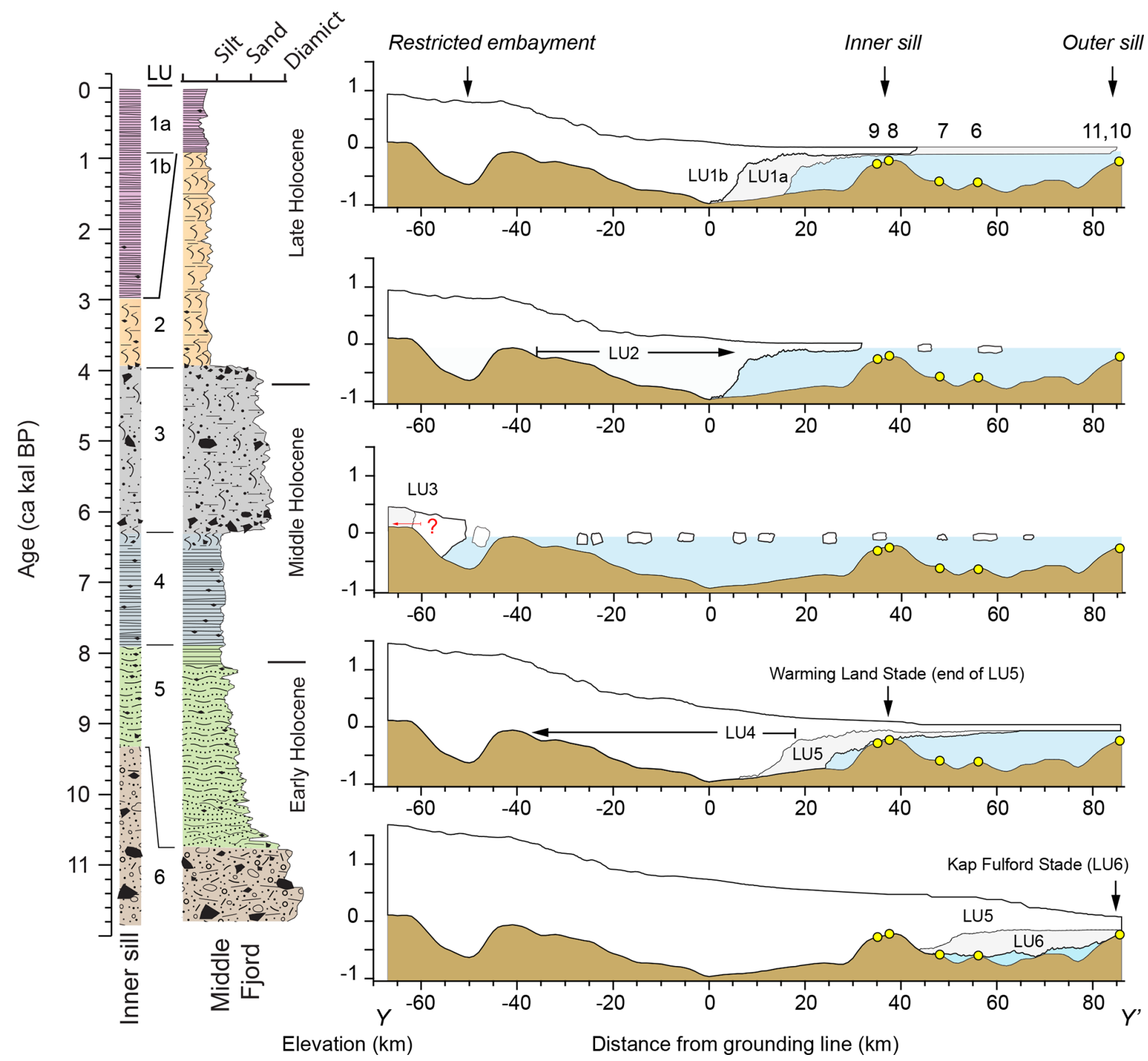

Figure 11. Generalized lithology and corresponding reconstructions of Ryder Glacier and ice tongue during deposition of the lithologic units. The profile location is illustrated in Fig. 11. The bathymetry was re-gridded from BedMachine v3 (Morlighem et al., 2017) after adding bathymetric data collected during the Ryder 2019 expedition. Substantial modifications to the former digital elevation model exist around the now mapped inner sill and beneath the modern ice tongue (see Supplement for details). Yellow dots indicate approximate positions of coring stations discussed in the text.

persistent iceberg calving, the slow melt-out of englacial material from the disintegrated ice tongue, and continued input of sea-ice-rafted material entrained during periods of shorefast sea-ice growth and decay.

In summary, our interpretation is that the end of LU3 $(3.9 \pm 0.4 \mathrm{cal}$ BP; Table 4$)$ marks the regrowth of a marinebased glacier and ice tongue. Importantly, this is consistent with existing dates constraining the onset of the Steensby Stade as described by Kelly and Bennike (1992). In particular, peat deposits over which Ryder's ice margin advanced during the Steensby Stade provide a Middle Holocene age of $5830 \pm 170 \mathrm{cal}$ BP (Station 41), while reworked marine macrofossils in lateral moraines at Steensby Glacier yield an age of $4560 \pm 410 \mathrm{cal}$ BP (Station 34; Kelly and Bennike, 1992). Therefore, while the re-advance of the local ice margin likely occurred prior to the Late Holocene, we argue that a marine-based glacier and ice tongue were not established until close to the Middle to Late Holocene transition. 

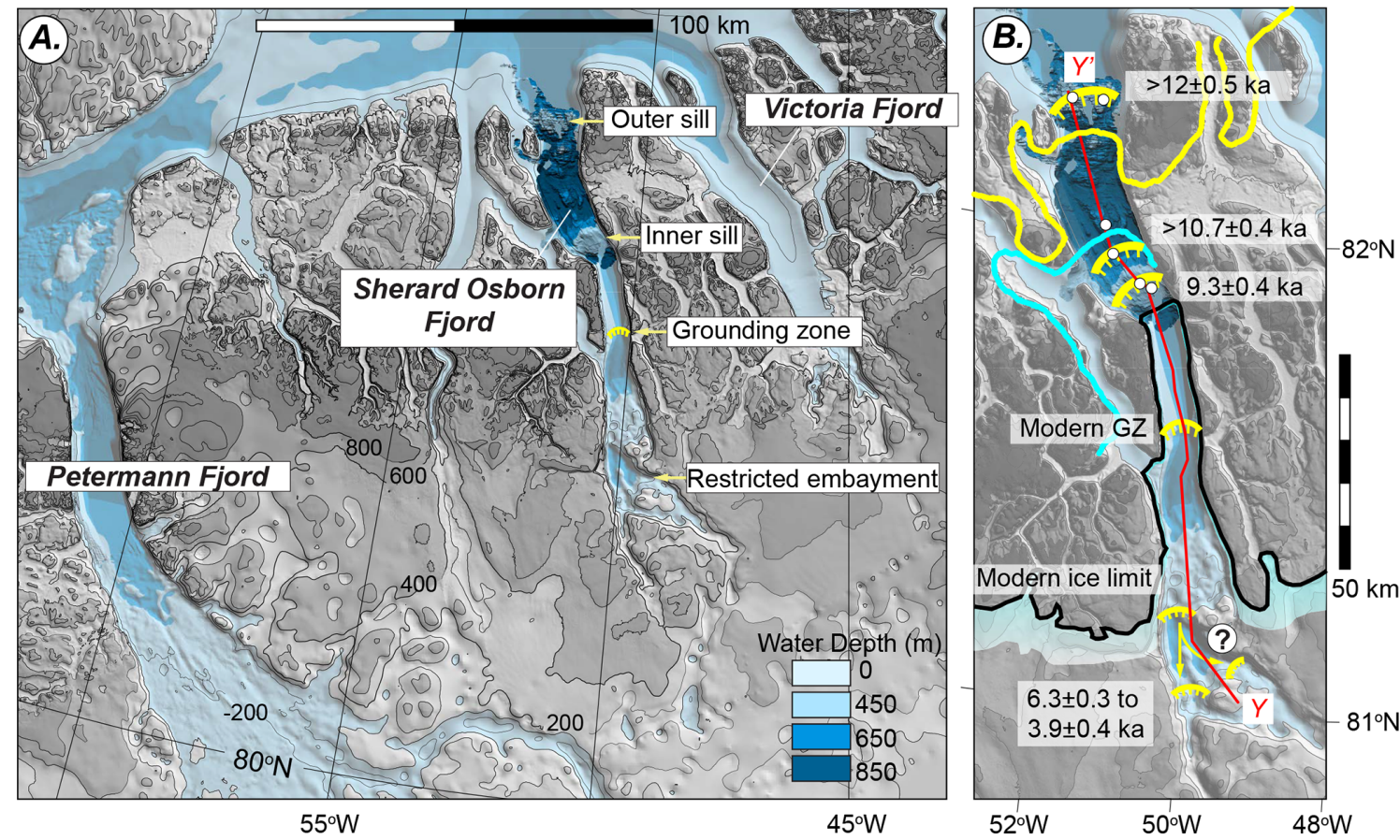

Figure 12. (a) Bathymetry and sub-glacial topography of north Greenland from Morlighem et al. (2017) illustrating pronounced differences between the broad submarine trough that extends inland from Petermann Glacier and the more restricted and rapidly shoaling topography in Sherard Osborn and Victoria Fjords. (b) Detail of Sherard Osborn Fjord showing the two mapped sills that correspond to the likely grounded limits of Ryder Glacier during the Kap Fulford and Warming Land stades. At the end of the Middle Holocene, Ryder Glacier likely retreated to a more inland position becoming largely land-based and cut off from the main fjord by the restricted embayment. White dots are the coring sites discussed in the text. The red line $\left(Y-Y^{\prime}\right)$ shows the position of the bathymetric profile used in Fig. 11. The bathymetry of Sherard Osborn Fjord has been updated from BedMachine V3 to include the incorporation of multi-beam mapping data from Ryder 2019 (Fig. S10). Ice margin positions during the Kap Fulford Stade (yellow line) and Warming Land Stade (blue line) are from Kelly and Bennike (1992). GZ = grounding zone.

\subsection{Late Holocene cooling and the regrowth of Ryder's ice tongue}

The advance of Ryder Glacier and the regrowth of local ice caps surrounding Sherard Osborn Fjord are described by the Steensby Stade re-advance. Its onset is not well constrained by terrestrial field data but is believed to have started sometime after 5.1-4.7 ka (Kelly and Bennike, 1992), with outlet glaciers reaching their maximum extents by the start of the 1900s. Thus, in marine records from Sherard Osborn Fjord, the Steensby Stade encompasses the deposition of LUs 2 and 1.

The highly bioturbated LU2 sediments appear abruptly on top of LU3, with the onset of deposition sometime after $3.9 \pm 0.4 \mathrm{ka}$ cal BP (Table 4). Increased sedimentation rates at the onset of LU2 (Fig. 10) likely mark the seaward migration of Ryder Glacier to a marine-based position in the innermost fjord. Within this setting, the regrowth of a limited ice tongue would act as a filter for coarse iceberg-rafted sediments and can explain the paucity of IRD in LU2. Extensive bioturbation in LU2 attests to warmer climatic conditions and the ab- sence of an ice tongue seaward of the mapped inner sill and possibly less persistent sea-ice cover.

On the inner sill, deposition of laminated sediments lacking bioturbation (LU1b) marks the regrowth of the ice tongue out to this location (Fig. 11) between $3.6 \pm 0.4$ and $2.9 \pm 0.4 \mathrm{ka} \mathrm{cal} \mathrm{BP}$. This is roughly $300-1000$ years after the glacier became marine-based at the end of LU3. The persistence of bioturbation (LU2) at stations in the middle fjord (stations 6 and 7) indicates an earlier establishment of the ice tongue over the inner sill, while more open water conditions persisted further seaward (Fig. 9). This configuration is similar to what we found during our expedition in 2019 (Fig. 2). It appears that this was a relatively stable configuration that persisted for another 2-2.7 kyr (until $0.9 \pm 0.3 \mathrm{ka} \mathrm{cal} \mathrm{BP}$; Table 4) before the ice shelf extended towards the outer sill and laminated LU1a sediments were deposited in the middle fjord (Figs. 10 and 11). The long-term stability of the ice tongue terminus near the inner sill is consistent with the inner sill acting as a barrier for Atlantic water invasion and limiting basal ice tongue melting (Jakobsson et al., 2020).

The Late Holocene regrowth of Ryder's ice tongue has some parallels with the Petermann ice tongue, which be- 
gan to reform between 1.9-2.3 kacal BP, after being absent since its collapse around $6.9 \mathrm{ka}$ cal BP (Reilly et al., 2019). Petermann also attained a stable ice tongue with an extent similar to 20th century historical observations between 0.4 0.9 ka cal BP (Reilly et al., 2019). At both Ryder and Petermann the growth of ice tongues towards the outer fjords occurred much later than the establishment of multi-year landfast sea ice in front of Phillips Inlet and Disraeli Fjord on northern Ellesmere Island around $5.5 \mathrm{kacal} \mathrm{BP}$ (England et al., 2008). On the other hand, ice tongue regrowth in Petermann (1.9-2.3 ka cal BP) and growth of Ryder's ice tongue to the inner sill in Sherard Osborn Fjord (by $2.9 \pm 0.4 \mathrm{ka} \mathrm{cal} \mathrm{BP}$ ) are consistent with the development of more extensive sea ice around the northern Greenland margin by $2.5 \mathrm{ka} \mathrm{cal} \mathrm{BP}$ (Funder et al., 2011a) and only intermittent periods of sea-ice free conditions in the Lincoln Sea after 3.9 ka cal BP based on the cessation of driftwood delivery to Clements Markham Inlet (England et al., 2008) (Fig. 10).

Uncertainty in the local reservoir correction leaves the timing for the maximum Late Holocene growth of Ryder's ice tongue poorly constrained. However, as with the final growth of Petermann's ice tongue (Reilly et al., 2019), it appears consistent with numerous regional paleoclimate records that document the development of cooler conditions close to the transition from the Medieval Warm Period to the Little Ice Age. For example, geochemical proxies from Bliss Lake (Fig. 1) indicate the onset of cooling around $850 \mathrm{cal} \mathrm{BP}$ (Olsen et al., 2012), which agrees with the onset of cooler air temperatures inferred from the $\delta^{18} \mathrm{O}$ record of the Hans Tausen ice cap around $780 \mathrm{cal}$ BP (Olsen et al., 2012; Hammer et al., 2001).

The absence of a thin bioturbated facies reflecting deposition since the 20th century retreat of Ryder's ice tongue is likely due to incomplete recovery of surface sediments in the studied cores. Given the predicted range of sedimentation rates for LU1a in 7PC (51-102 cm/kyr; Fig. 10), only 4-8 cm of sediment would have accumulated since the retreat of Ryder's ice tongue to its current position $\sim 80$ years ago. This thin sedimentary cover could easily have been missed during coring, especially considering the soft nature of surface sediments encountered in the fjord.

\subsection{Controls on the Holocene dynamics of Ryder Glacier}

The retreat of Ryder Glacier from the fjord mouth $(>10.7 \pm$ $0.4 \mathrm{kacal} \mathrm{BP}$ ) is consistent with the demise of glacial ice across much of northern Greenland in the Early Holocene (Bennike and Björck, 2002; Larsen et al., 2010; Strunk et al., 2018; Larsen et al., 2018). During the early stages of deglaciation, the Lincoln Sea was covered by thick shelf ice fed by coalescent glaciers emanating from Greenland and Ellesmere Island (England, 1999; Larsen et al., 2010). This eastward flowing shelf ice overrode parts of the north Greenland coast (Johannes V. Jensen Land; Fig. 1) with its final breakup occurring between 10.3-10.1 ka cal BP (Larsen et al., 2010). Reduced sea-ice conditions in the Lincoln Sea at this time are evidenced by the onset and persistence of driftwood delivery to Clements Markham Inlet (Fig. 9; England et al., 2008) after glacial ice had retreated from the northernmost Nares Strait at $>10.1$ ka (England et al., 1999). Future work on sediment cores from Ryder 2019 utilizing paleoenvironmental proxies for sea ice and oceanographic conditions may help resolve how atmospheric warming (Cook et al., 2019) and warm Atlantic water advection (Wood et al., 2021) into the Lincoln Sea influenced Holocene glacier retreat.

Ryder Glacier retreated much earlier than Petermann Glacier to the south (Jakobsson et al., 2018; Reilly et al., 2019). Petermann Glacier remained grounded at the mouth of Petermann Fjord, bordering Hall Basin, until 7.5 ka cal BP (Jakobsson et al., 2018) even after Ryder had retreated from the inner sill and was $>40 \mathrm{~km}$ from the mouth of Sherard Osborn Fjord. In this respect, it is important to acknowledge that Petermann's retreat from the outer fjord was one of the final events that occurred during deglaciation of Nares Strait and specifically of Hall Basin (Jakobsson et al., 2018). Glacial ice in Hall Basin had remained in an advanced position abutting Robeson Channel until $9.3 \mathrm{ka} \mathrm{cal} \mathrm{BP}$ (Fig. 1; Jakobsson et al., 2018; England, 1999). The ice margin had receded to the mouth of Petermann Fjord by $8.7 \mathrm{ka}$ cal BP prior to the opening of Nares Strait between 8 and $8.5 \mathrm{kacal}$ BP (Jennings et al., 2011, 2019; Georgiadis et al., 2018). Therefore, differences in the timing of retreat between Petermann and Ryder glaciers appears closely tied to local glacial and seaice conditions. These appear to have been less severe and more mobile in the Lincoln Sea in the Early Holocene compared to the Nares Strait region.

The sedimentary facies from Sherard Osborn Fjord documents seemingly gradual retreat and regrowth phases for Ryder Glacier as evidenced by the generally low abundance of coarse IRD (Fig. 10) and the absence of lenses or pulses of IRD that would otherwise indicate ice tongue collapse events. For example, in Petermann Fjord the collapse of the ice shelf at $6.9 \mathrm{ka}$ cal BP is marked in sedimentary records by the abrupt appearance of IRD clasts in sediments from across the fjord (Reilly et al., 2019). The stability of Ryder Glacier's ice tongue is most likely related to the physiography of Sherard Osborn Fjord.

The inner sill in Sherard Osborn Fjord not only acts as a natural pinning point for glacial ice during its retreat but also impedes the flow of warm Atlantic subsurface waters into the innermost fjord (Fig. 3; Jakobsson et al., 2020). This likely reduces the subaqueous melting at the grounding zone and of the ice tongue today and may have done so efficiently for much of the Holocene. The subglacial bed topography and physiography of the inner fjord will also exert an influence on glacier (and hence ice tongue) stability. There appears to be a slight retrograde slope between the inner sill and modern grounding zone (Fig. 11), which are common in northern 
Greenland fjords and can be conducive to rapid glacial retreat (Enderlin et al., 2013; Carr et al., 2015; Hill et al., 2018). However, Sherard Osborn Fjord also narrows considerably landward of the inner sill and remains flanked by steep-sided cliffs (Fig. 12). Jamieson et al. (2012) have shown that even on a retrograde slope, retreating ice streams slow or can become pinned where they pass narrow sections in surrounding topography. The sedimentary record from seaward of the inner sill contains no evidence for massive calving events that would otherwise suggest a collapse of the ice tongue during a rapid retreat down a retrograde slope. However, there is tremendous uncertainty regarding the bathymetry beneath the current ice tongue as no direct measurements exist, so even the presence of a retrograde slope is not certain. A more certain feature of the bathymetry is the steeply rising bed topography landward of the modern grounding zone (Figs. 11 and 12). This feature, which could be a former grounding zone, may have promoted the gradual retreat of Ryder Glacier and the stability of its ice tongue during the Early and Middle Holocene (Powell, 1990; Alley, 1991; Hill et al., 2018). A critical observation is that despite the apparent persistence of Ryder's ice tongue, the physiographic setting of Sherard Osborn Fjord, which appears to be conducive to glacier stability, did not halt the overall retreat of Ryder Glacier under the relatively mild changes in climate forcing during the Holocene.

From the results of this study, it is not possible to constrain the amount of inland retreat Ryder Glacier experienced during the Middle Holocene. Based on the cessation of sedimentation in the outer fjord, we suggest that it may have retreated at least into the restricted embayment at the end of Sherard Osborn Fjord (Figs. 11 and 12). Unlike Petermann Glacier, where the bed topography widens and extends far beneath the GrIS at elevations below modern sea level, the bed of Ryder Glacier abruptly rises above sea level some $60 \mathrm{~km}$ landward of the modern grounding line (Fig. 12). This is comparable to the smaller glaciers in the immediate surroundings and to the Køge Bugt glacier complex in southeast Greenland, where the steep land-ocean boundary limited the Middle Holocene retreat of the glaciers in this area (Dyke et al., 2017). This suggests that the land-ocean interface might have been an important boundary that mediated or halted the Holocene retreat of many glaciers that are not located in deep troughs that extend beneath the inner ice sheet. Overall, our constraints on the Holocene dynamics of Ryder Glacier suggest that it could retreat another 40-60 km inland if climatic conditions remain similar to or exceed those of the Middle Holocene.

\section{Conclusions}

Like much of northern Greenland, Ryder Glacier responded acutely to climate variability in the Holocene. During the Early and Middle Holocene it retreated over $120 \mathrm{~km}$ from a grounded position near the mouth of Sherard Osborn Fjord
( $80 \mathrm{~km}$ seaward of the modern grounding zone) to likely become land-based more than $40-60 \mathrm{~km}$ landward of its current position by $6.3 \pm 0.3 \mathrm{kacalBP}$. Throughout this long period of retreat, deposition of laminated, clast-poor sediments attest to strong meltwater inputs and an overall stable ice tongue. Ryder Glacier remained land-based until the Late Holocene ( $3.9 \pm 0.4 \mathrm{ka} \mathrm{cal} \mathrm{BP})$. As it again advanced into Sherard Osborn Fjord, an ice tongue developed that quickly grew out to its 21 st century position near a prominent bathymetric sill, located $30 \mathrm{~km}$ seaward of the modern grounding zone. Today this sill reduces the incursion of Atlantic waters into the inner fjord and shields the grounding zone and ice tongue from basal melting (Jakobsson et al., 2020). This was also likely the case for 2.0-2.7 kyr in the Late Holocene, before the ice tongue grew to its historical maximum extent around $0.9 \pm 0.3 \mathrm{kacal}$ BP. Late Holocene bioturbated sediments that are nearly devoid of ice-rafted debris were deposited between $3.9 \pm 0.4$ and $0.9 \pm 0.3 \mathrm{ka} \mathrm{cal} \mathrm{BP}$ and indicate reduced ice cover over much of the middle and outer fjord. This contrasts with the near permanent shore-fast ice conditions that existed in Sherard Osborn Fjord for much of the late 20th century (Higgins, 1989), but it is similar to conditions during the summer of 2019. The physiography of Sherard Osborn Fjord appears to have had a stabilizing effect on the ice tongue of Ryder Glacier through the Holocene. Nevertheless, Ryder Glacier still retreated $>40-60 \mathrm{~km}$ landward of its current position and remained there under the relatively mild climate forcing in the Middle Holocene, suggesting that it may again retreat completely from the fjord to an inland position if climate warming continues at its current pace.

Data availability. Data from the Ryder 2019 expedition are available through the Bolin Centre Database at the Bert Bolin Centre for Climate Research (https://bolin.su.se/data/ ryder-2019-expedition-2, last access: 14 August 2021). Marine bathymetry data are available at https://doi.org/10.17043/ryder2019-bathymetry (Calder et al., 2020), CTD measurements at https://doi.org/10.17043/ryder-2019-ctd (Stranne et al., 2020), MSCL data from sediment cores at https://doi.org/10.17043/odenryder-2019-sediment-mscl-1 (O'Regan, 2021a), and XRF-scanning data at https://doi.org/10.17043/oden-ryder-2019-sediment-xrf-1 (O’Regan, 2021b).

Supplement. The supplement related to this article is available online at: https://doi.org/10.5194/tc-15-4073-2021-supplement.

Author contributions. This article was written by MO'R with subsequent input from all co-authors. MJ and LAM led the Ryder 2019 expedition. Cores were collected and processed shipboard by MO'R, TMC, BR, GW, and LG. Shore-based analyses were conducted by MO'R, BR, FV, CP, GW, AKOA, OLM, AG, MattM, and HD. CS and JN collected, processed and interpreted the oceano- 
graphic data. MathM provided the improved digital elevation model for Sherard Osborn Fjord.

Competing interests. The authors declare that they have no conflict of interest.

Disclaimer. Any use of trade, firm, or product names is for descriptive purposes only and does not imply endorsement by the US government.

Publisher's note: Copernicus Publications remains neutral with regard to jurisdictional claims in published maps and institutional affiliations.

Acknowledgements. We are grateful to the captain and crew of icebreaker Oden and personnel from the Swedish Polar Research Secretariat for their support during the planning and execution of the Ryder 2019 expedition. This expedition was endorsed as Explorers Club Flag Expedition \#51. We thank June Padman (Oregon State University) and Carina Johansson (Stockholm University) for their help in shipboard core processing.

Financial support. The Swedish Polar Research Secretariat, Center for Coastal and Ocean Mapping, University of New Hampshire, and Stockholm University supported the Ryder 2019 expedition financially. Matt O'Regan, Martin Jakobsson, Christian Stranne, and colleagues from Stockholm University were supported by grants from the Swedish Research Council (VR; grants 2016-05092, 2016-04021, 2018-04350). Thomas M. Cronin and Laura Gemery were supported by the USGS Land Change Program.

The article processing charges for this open-access publication were covered by Stockholm University.

Review statement. This paper was edited by Chris R. Stokes and reviewed by two anonymous referees.

\section{References}

Alley, R. B.: Sedimentary processes may cause fluctuations of tidewater glaciers, Ann. Glaciol., 15, 119-124, 1991.

Axford, Y., Lasher, G. E., Kelly, M. A., Osterberg, E. C., Landis, J., Schellinger, G. C., Pfeiffer, A., Thompson, E., and Francis, D. R.: Holocene temperature history of northwest Greenland - With new ice cap constraints and chironomid assemblages from Deltasø, Quaternary Sci. Rev., 215, 160-172, https://doi.org/10.1016/j.quascirev.2019.05.011, 2019.

Bamber, J. L., Oppenheimer, M., Kopp, R. E., Aspinall, W. P., and Cooke, R. M.: Ice sheet contributions to future sea-level rise from structured expert judgment, P. Natl. Acad. Sci. USA, 116, 11195, https://doi.org/10.1073/pnas.1817205116, 2019.
Bennike, O. and Björck, S.: Chronology of the last recession of the Greenland ice sheet, J. Quaternary Sci., 17, 211-219, 2002.

Bennike, O. and Kelly, M.: Radiocarbon dating of samples collected during the 1984 expedition to North Greenland, Rapp. Grønlands geol. Unders., 135, 8-10, 1987.

Bogen, J., Xu, M., and Kennie, P.: The impact of pro-glacial lakes on downstream sediment delivery in Norway, Earth Surf. Proc. Land., 40, 942-952, https://doi.org/10.1002/esp.3669, 2015.

Briner, J. P., McKay, N. P., Axford, Y., Bennike, O., Bradley, R. S., de Vernal, A., Fisher, D., Francus, P., Frechette, B., Gajewski, K., Jennings, A., Kaufman, D. S., Miller, G., Rouston, C., and Wagner, B.: Holocene climate change in Arctic Canada and Greenland, Quaternary Sci. Rev., 147, 340-364, https://doi.org/10.1016/j.quascirev.2016.02.010, 2016.

Bronk Ramsey, C.: Bayesian analysis of radiocarbon dates, Radiocarbon, 51, 337-360, 2009,

Cage, A. G., Pieńkowski, A. J., Jennings, A., Knudsen, K. L., and Seidenkrantz, M.-S.: Comparative analysis of six common foraminiferal species of the genera Cassidulina, Paracassidulina, and Islandiella from the Arctic-North Atlantic domain, J. Micropalaeontol., 40, 37-60, https://doi.org/10.5194/jm-4037-2021, 2021.

Calder, B., Eriksson, B., Jerram, K., Weidner, E., Holmes, F., Muchowski, J., Prakash, A., Handl, T., Ståhl, E., Mayer, L., and Jakobsson, M.: High-resolution bathymetry from the Ryder 2019 expedition to Northwest Greenland, Dataset version 1.0, Bolin Centre Database [data set], https://doi.org/10.17043/ryder-2019bathymetry, 2020.

Carr, J. R., Vieli, A., Stokes, C. R., Jamieson, S. S. R., Palmer, S. J., Christoffersen, P., Dowdeswell, J. A., Nick, F. M., Blankenship, D. D., and Young, D. A.: Basal topographic controls on rapid retreat of Humboldt Glacier, Northern Greenland, J. Glaciol., 61, 137-150, https://doi.org/10.3189/2015JoG14J128, 2015.

Carrivick J. L. and Tweed F. S.: Proglacial lakes: character, behavior and geological importance, Quaternary Sci. Rev., 78, 34-52, 2013.

Cook, A. J., Copland, L., Noel, B., Stokes, C. R., Bentley, M., Sharp, M. J., Bingham, R. G., and van den Broeke, M. R.: Atmospheric forcing of rapid marine-terminating glacier retreat in the Canadian Arctic Archipelago, Sci. Adv., 5, eaau8507, https://doi.org/10.1126/sciadv.aau8507, 2019.

Coulthard, R. D., Furze, M. F. A., Pienkowski, A. J., Chantel Nixon, F., England, J. H.: New marine DR values for Arctic Canada, Quaternary Geochronol., 5, 419-434, https://doi.org/10.1016/j.quageo.2010.03.002, 2010.

Cronin, T. M., Seidenstein, J., Keller, K., McDougall, K., Reufer, A., and Gemery, L., The benthic foraminifera cassidulina from the Arctic Ocean: Application to paleoceanography and biostratigraphy, Micropaleontology, 65, 105-125, 2019.

Davies, V. E. and Krinsley, D. B.: The recent regimen of the ice cap margin in North Greenland, Assoc. Internat. d'Hydrologie Sci., 58, 119-130, 1962.

Dowdeswell, J. A., Whittington, R., and Marienfield, P.: The origin of massive diamicton facies by iceberg rafting and scouring, Scoresby Sund, East Greenland, Sedimentology, 41, 21-35, 1994.

Dyke, L. M., Andresen, C. S., Seidenkrantz, M.-S., Hughes, A. L. C., Hiemstra, J. F., Murray, T., Bjørk, A. A., Sutherland, D. A., and Vermassen, F.: Minimal Holocene retreat of large tidewater 
glaciers in Køge Bugt, southeast Greenland, Sci. Rep., 7, 12330, https://doi.org/10.1038/s41598-017-12018-x, 2017.

Enderlin, E. M., Howat, I. M., and Vieli, A.: High sensitivity of tidewater outlet glacier dynamics to shape, The Cryosphere, 7, 1007-1015, https://doi.org/10.5194/tc-7-1007-2013, 2013.

England, J.: Coalescent Greenland and Innuitian ice during the Last Glacial Maximum: revising the Quaternary of the Canadian High Arctic, Quaternary Sci. Rev., 18, 421-456, https://doi.org/10.1016/S0277-3791(98)00070-5, 1999.

England, J. H., Lakeman, T. R., Lemmen, D. S., Bednarski, J. M., Stewart, T. G., and Evans, D. J. A.: A millennial-scale record of Arctic Ocean sea ice variability and the demise of the Ellesmere Island ice shelves, Geophys. Res. Lett., 35, L19502, https://doi.org/10.1029/2008GL034470, 2008.

Funder, S.: 14C-dating of samples collected during the 1979 expedition to North Greenland, Rapport Grønlands Geologiske Undersøgelse, 110, 9-14, https://doi.org/10.34194/rapggu.v110.7787, 1982.

Funder, S., Goosse, H., Jepsen, H., Kaas, E., Kjaer, K. H., Korsgaard, N. J., Larsen, N. K., Linderson, H., Lysa, A., Moller, P., Olsen, J., and Willerslev, E.: A 10,000-year record of Arctic Ocean sea-ice variability - view from the beach, Science, 333, 747-750, https://doi.org/10.1126/science.1202760, 2011a.

Funder, S., Kjeldsen, K. K., Kjær, K. H., and O Cofaigh, C.: The Greenland ice sheet during the past 300,000 Years, Dev. Quaternary Sci., 15, 699-713, https://doi.org/10.1016/B978-0-44453447-7.00050-7, 2011b.

Georgiadis, E., Giraudeau, J., Martinez, P., Lajeunesse, P., StOnge, G., Schmidt, S., and Massé, G.: Deglacial to postglacial history of Nares Strait, Northwest Greenland: a marine perspective from Kane Basin, Clim. Past, 14, 1991-2010, https://doi.org/10.5194/cp-14-1991-2018, 2018.

Hammer, C. U., Johnsen, S. J., Clausen, H. B., Dahl-Jensen, D., Gundestrup, N., and Steffensen, J. P.: The paleoclimatic record from a $345 \mathrm{~m}$ long ice core from the Hans Tausen Iskappe, Meddelelser Om. Grønl. Geosci., 39, 87-95, 2001.

Hatfield, R. G., Stoner, J. S., Reilly, B. T., Tepley, F. J., Wheeler, B. H., Housen, B. A.: Grain size dependent magnetic discrimination of Iceland and South Greenland terrestrial sediments in the northern North Atlantic sediment record, Earth Planet. Sci. Lett., 474, https://doi.org/10.1016/j.eps1.2017.06.042, 2017.

Heaton, T., Köhler, P., Butzin, M., Bard, E., Reimer, R., Austin, W., Bronk Ramsey, C., Grootes, P. M., Hughen, K. A., Kromer, B., Reimer, P. J., Adkins, J., Burke, A., Cook, M. S., Olsen, J., and Skinner, L.: Marine20 - The Marine Radiocarbon Age Calibration Curve (0-55,000 cal BP), Radiocarbon, 62, 779-820, https://doi.org/10.1017/RDC.2020.68, 2020.

Henriksen, N. and Higgins, A. K.: 2000. Early Palaeozoic Basin Development of North Greenland - Part of the Franklinian Basin, Polarforschung, 68, 131-140, 2020.

Henriksen, N., Higgins, A., Kalsbeek, F., and Pulvertaft, T. C. R.: Greenland from Archaean to Quaternary. Descriptive text to the 1995 Geological map of Greenland, 1:2 500 000. 2nd edition, GEUS Bulletin, 18, 1-126, https://doi.org/10.34194/geusb.v18.4993, 2009.

Higgins, A. K.: North Greenland ice islands, Polar Record, 25, $207-$ 212,1989

Higgins, A. K.: North Greenland glacier velocities and calf ice production, Polarforschung, 60, 1-23, 1990.
Higgins, A. K., Soper, N. J., and Leslie, A. G.: The Ellesmerian and Caledonian Orogenic Belts of Greenland, Polarforschung, 68, 141-151, 1998.

Hill, E. A., Carr, J. R., and Stokes, C. R.: A Review of Recent Changes in Major Marine-Terminating Outlet Glaciers in Northern Greenland, Front. Earth Sci., 4, 111, https://doi.org/10.3389/feart.2016.00111, 2017.

Hill, E. A., Carr, J. R., Stokes, C. R., and Gudmundsson, G. H.: Dynamic changes in outlet glaciers in northern Greenland from 1948 to 2015, The Cryosphere, 12, 3243-3263, https://doi.org/10.5194/tc-12-3243-2018, 2018.

Hogan, K. A., Jakobsson, M., Mayer, L., Reilly, B. T., Jennings, A. E., Stoner, J. S., Nielsen, T., Andresen, K. J., Nørmark, E., Heirman, K. A., Kamla, E., Jerram, K., Stranne, C., and Mix, A.: Glacial sedimentation, fluxes and erosion rates associated with ice retreat in Petermann Fjord and Nares Strait, north-west Greenland, The Cryosphere, 14, 261-286, https://doi.org/10.5194/tc-14-261-2020, 2020.

Jakobsson, M., Hogan, K. A., Mayer, L. A., Mix, A., Jennings, A., Stoner, J., Eriksson, B., Jerram, K., Mohammad, R., Pearce, C., Reilly, B., and Stranne, C.: The Holocene retreat dynamics and stability of Petermann Glacier in northwest Greenland, Nat. Commun., 9, 2104, https://doi.org/10.1038/s41467-018-045732, 2018

Jakobsson, M., Mayer, L., Nilsson, J., Stranne, C., Calder, B., O'Regan, M., Mix, A., and Ryder19 Shipboard Scientific Party: Ryder Glacier in northwest Greenland is shielded from warm Atlantic water by a bathymetric sill, Nat. Commun. Earth Environ., 1, 45, https://doi.org/10.1038/s43247-020-00043-0, 2020.

Jamieson, S. S. R., Vieli, A., Livingstine, S. J., Ó Cofaigh, C., Stokes, C., Hillenbrand, C.-D., and Dowdeswell, J.: Ice-stream stability in a reverse bed slope, Nat. Geosci., 5, 799-802, https://doi.org/10.1038/NGEO1600, 2012.

Jennings, A. E., Sheldon, C., Cronin, T. M., Francus, P., Stoner, J., and Andrews, J.: The Holocene history of Nares Strait: Transition from glacial bay to Arctic-Atlantic throughflow, Oceanography, 24, 18-33, 2011.

Jennings, A. E., Andrews, J. T., Oliver, B., Walczak, M., and Mix, A.:Retreat of the Smith Sound Ice Stream in the Early Holocene, Boreas, 48, 825-840, https://doi.org/10.1111/bor.12391, 2019.

Kaufman, D., Ager, T., Anderson, N., Anderson, P., Andrews, J., Bartlein, P., Brubaker, L., Coats, L., Cwynar, L., Duvall, M., Dyke, A., Edwards, M., Eisner, W., Gajewski, K., Geirsdóttir, A., Hu, F., Jennings, A., Kaplan, M., Kerwin, M., Lozhkin, A., MacDonald, G., Miller, G., Mock, C., Oswald, W., Otto-Bliesner, B., Porinchu, D., Rühland, K., Smol, J., Steig, E., and Wolfe, B.: Holocene thermal maximum in the western Arctic (0-180 $\left.{ }^{\circ} \mathrm{W}\right)$, Quaternary Sci. Rev., 23, 529-560, https://doi.org/10.1016/J.QUASCIREV.2003.09.007, 2004.

Kelly, M. and Bennike, O.: Quaternary geology of parts of central and western North Greenland: a preliminary account, Rapp. Grønlands Geol. Unders., 126, 111-116, 1985.

Kelly, M. and Bennike, O.: Quaternary Geology of Western and Central North Greenland, Rapp. Grønlands Geol. Unders., Copenhagen, 153, 34 pp., 1992.

Koch, L.: Contributions to the glaciology of North Greenland, Meddelelser om Grønland, 65, 181-464, 1928.

Landvik, J. Y., Weidick, A., and Hansen, A.: The glacial history of the Hans Tausen Iskappe and the last glaciation of Peary Land, 
North Greenland, Meddelelser Om. Grønl. Geosci., 39, 27-44, 2001.

Larsen, N. K., Kjaer, K. H., Funder, S., Möller, P., van der Meer, J. J. M., Schomacker, A., Linge, H., and Darby, D. A.: Late Quaternary glaciation history of northernmost Greenland Evidence of shelf-based ice, Quaternary Sci. Rev., 29, 3339-3414, https://doi.org/10.1016/j.quascirev.2010.07.027, 2010.

Larsen, N. K., Levy, L. B., Carlson, A. E., Buizert, C., Olsen, J., Strunk, A., Bjørk, A. A., and Skov, D. S.: Instability of the Northeast Greenland Ice Stream over the last 45,000 years, Nat. Commun., 9, 1872, https://doi.org/10.1038/s41467-018-043127, 2018.

Larsen, N. K., Levy, L. B., Strunk, A., Søndergaard, A. S., Olsen, J., and Lauridsen, T. L.: Local ice caps inFinderup Land, North Greenland, survived the Holocene Thermal Maximum, Boreas, 48, 551-562, https://doi.org/10.1111/bor.12384, 2019.

Lasher, G. E., Axford, Y., McFarlin, J. M., Kelly, M. A., Osterberg, E. C., and Berkelhammer, M. B.: Holocene temperatures and isotopes of precipitation in Northwest Greenland recorded in lacustrine organic materials, Quaternary Sci. Rev., 170, 45-55, https://doi.org/10.1016/j.quascirev.2017.06.016, 2017.

Lecavalier, B. S., Fisher, D. A., Milne, G. A., Vinther, B. M., Tarasov, L., Huybrechts, P., Lacelle, D., Main, B., Zheng, J., Bourgeois, J., and Dyke, A. S.: High Arctic Holocene temperature record from the Agassiz ice cap and Greenland ice sheet evolution, P. Natl. Acad. Sci. USA, 114, 5952-5957, https://doi.org/10.1073/pnas.1616287114, 2017

Madsen, K. N. and Thorsteinsson, T.: Textures, fabrics and meltlayer stratigraphy in the Hans Tausen ice core, North Greenland - indications of late Holocene ice cap generation?, Meddelelser Om. Grønl. Geosci., 39, 97-114, 2001.

McFarlin, J. M., Axford, Y., Osburn, M. R., Kelly, M. A., Osterberg, E. C., and Farnsworth, L. B.: Pronounced summer warming in northwest Greenland during the Holocene and Last Interglacial, P. Natl. Acad. Sci. USA, 201720420, https://doi.org/10.1073/pnas.1720420115, 2018.

Miller, G. H., Alley, R. B., Brigham-Grette, J., Fitzpatrick, J. J., Polyak, L., Serreze, M. C., and White, J. W. C.: Arctic amplification: can the past constrain the future?, Quaternary Sci. Rev., 29, 1779-1790, https://doi.org/10.1016/j.quascirev.2010.02.008, 2010.

Möller, P., Larsen, N. K., Kjær, K. H., Funder, S., Schomacker, A., Linge, H., and Fabel, D.: Early to middle Holocene valley glaciations on northernmost Greenland, Quaternary Sci. Rev., 29, 3379-3398, https://doi.org/10.1016/j.quascirev.2010.06.044, 2010.

Mörner, N.-A. and Funder, S.: C-14 dating of samples collected during the NORQUA 86 expedition, and notes on the marine reservoir effect, Meddelelser om Grønland, 22, 57-59, 1990.

Moon, T. and Joughin, I.: Changes in ice front position on Greenland's outlet glaciers from 1992 to 2007, J. Geophys. Res.-Earth, 113, 1-10, https://doi.org/10.1029/2007JF000927, 2008.

Moon, T., Joughin, I., Sith, B., and Howat, I.: 21st-century evolution of Greenland outlet glacier velocities, Science, 336, 576578, https://doi.org/10.1126/science.1219985, 2012.

Morlighem, M., Williams, C. N., Rignot, E., An, L., Arndt, J. E., Bamber, J. L., Catania, G., Chauché, N., Dowdeswell, J. A., Dorschel, B., Fenty, I., Hogan, K., Howat, I., Hubbard, A., Jakobsson, M., Jordan, T. M., Kjeldsen, K. K., Millan, R., Mayer,
L. A., Mouginot, J., Noël, B. P. Y., O’Cofaigh, C., Palmer, S., Rysgaard, S., Seroussi, H., Siegert, M. J., Slabon, P., Straneo, F., van den Broeke, M. R., Weinrebe, W., Wood, M., and Zinglersen, K. B.: BedMachine v3: Complete Bed Topography and Ocean Bathymetry Mapping of Greenland From Multibeam Echo Sounding Combined With Mass Conservation, Geophys. Res. Lett. , 44, 11051-11061, 2017.

Mottram, R., Simonsen, S., Høyer Svendsen, S., Barletta, V. R., Sandberg Sørensen, L., Nagler, T., Wuite, J., Groh, A., Horwath, M., Rosier, J., Solgaard, A., Hvidberg, C. S., and Forsberg, R.: An Integrated View of Greenland Ice Sheet Mass Changes Based on Models and Satellite Observations, Remote Sens., 11, 1407, https://doi.org/10.3390/rs11121407, 2019.

Mouginot, J., Rignot, E., Bjørk, A. A., van den Broeke, M., Millan, R., Morlighem, M., Noël, B., Scheuchl, B., and Wood, M.: Forty-six years of Greenland Ice Sheet mass balance from 1972 to 2018, P. Natl. Acad. Sci. USA, 116, 9239-9244, 2019.

Nagler, T., Rott, H., Hetzenecker, M., Wuite, J., and Potin, P.: The Sentinel-1 Mission: New Opportunities for Ice Sheet Observations, Remote Sensing, 7, 9371-9389, https://doi.org/10.3390/rs70709371, 2015.

O'Cofaigh, C. and Dowdeswell, J. A.: Laminated sediments in glacimarine environments: diagnostic criteria for their interpretation, Quaternary Sci. Rev., 20, 1411-1436, 2001.

Olsen, J., Kjær, K. H., Funder, S., Larsen, N. K., and Ludikova, A.: High-Arctic climate conditions for the last 7000 years inferred from multi-proxy analysis of the Bliss Lake record, North Greenland, J. Quaternary Sci., 27, 318-327, https://doi.org/10.1002/jqs.1548, 2012.

O'Regan, M.: Physical properties of marine sediment cores from the Ryder 2019 expedition, Dataset version 1.0, Bolin Centre Database [data set], https://doi.org/10.17043/oden-ryder-2019sediment-mscl-1, 2021a.

O'Regan, M.: Geochemical XRF core scanning data of marine sediment cores from the Ryder 2019 expedition, Dataset version, Bolin Centre Database [data set], https://doi.org/10.17043/odenryder-2019-sediment-xrf-1, 2021b.

Piret, L., Bertrand, S., Hawkings, J., Kylander, M. E., Torrejón, F., Amann, B., and Wadham, J.: High-resolution fjord sediment record of a receding glacier with growing intermediate proglacial lake (Steffen Fjord, Chilean Patagonia), Earth Surf. Proc. Land., 46, 239-251, https://doi.org/10.1002/esp.5015, 2021.

Powell, R. D.: Glacimarine processes at grounding line fans and their growth to ice-contact deltas, Geol. Soc. London, Spec. Publ., 53, 53-73, https://doi.org/10.1144/GSL.SP.1990.053.01.03, 1990.

Reilly, B. T., Stoner, J. S., and Wiest, J.: SedCT: MATLABTM tools for standardized and quantitative processing of sediment core computed tomography (CT) data collected using a medical CT scanner, Geochem. Geophys. Geosyst., 18, 3231-3240, https://doi.org/10.1002/2017GC006884, 2017.

Reilly, B. T., Stoner, J. S., Mix, A. C., Walczak, M. H., Jennings, A., Jakobsson, M., Dyke, L., Glueder, A., Nicholls, K., Hogan, K. A., Mayer, L. A., Hatfield, R. G., Albert, S., Marcott, S., Fallon, S., and Cheseby, M.: Holocene break-up and reestablishment of the Petermann Ice Tongue, Northwest Greenland, Quaternary Sci. Rev., 218, 322-342, https://doi.org/10.1016/j.quascirev.2019.06.023, 2019. 
Reimer, P. J., Baillie, M. G. L., Bard, E., Bayliss, A., Beck, J. W., Blackwell, P. G., Bronk- Ramsey, C., Buck, C. E., Burr, G. S., Edwards, R. L., Friederich, M., Grootes, P. M., Guilderson, T. P., Hajdas, I., Heaton, T. J., Hogg, A. G., Hughen, K. A., Kaiser, K. F., Kromer, B., McCormac, F. G., Manning, S., Reimer, R. W., Richards, D. A., Southon, J. R., Talamo, S., Turney, C. S. M., van der Plicht, J., and Weyhenmeyer, C. E.: IntCal09 and Marine09 radiocarbon age calibration curves, 0-50,000 years cal BP, Radiocarbon, 51, 1111-1150, 2009.

Reimer, P. J., Bard, E., Bayliss, A., Beck, J. W., Blackwell, P. G., Ramsey, C. B., Buck, C. E., Cheng, H., Edwards, R. L., Friedrich, M., Grootes, P. M., Guilderson, T. P., Haflidason, H., Hajdas, I., Hatté, C., Heaton, T. J., Hoffmann, D. L., Hogg, A. G., Hughen, K. A., Kaiser, K. F., Kromer, B., Manning, S. W., Niu, M., Reimer, R. W., Richards, D. A., Scott, E. M., Southon, J. R., Staff, R. A., Turney, C. S. M., and van der Plicht, J.: IntCal13 and Marine13 radiocarbon age calibration curves 0-50,000 Years cal BP, Radiocarbon, 55, 1869-1887, https://doi.org/10.2458/azu_js_rc.55.16947, 2013.

Smith, J. A., Graham, A. G. C., Post, A. L., Hillenbrand, C.D., Bart, P. J., and Powell, R. D.: The marine geological imprint of Antarctic ice shelves, Nat. Commun., 10, 5635, https://doi.org/10.1038/s41467-019-13496-5, 2019.

Søndergaard, A. S., Larsen, N. K., Steinemann, O., Olsen, J., Funder, S., Egholm, D. L., and Kjær, K. H.: Glacial history of Inglefield Land, north Greenland from combined in situ ${ }^{10} \mathrm{Be}$ and ${ }^{14} \mathrm{C}$ exposure dating, Clim. Past, 16, 1999-2015, https://doi.org/10.5194/cp-16-1999-2020, 2020.

Stranne, C., Nilsson, J., Muchowski, J., and Chawarski, J.: Oceanographic CTD data from the Ryder 2019 expedition, Dataset version 1.0, Bolin Centre Database [data set], https://doi.org/10.17043/ryder-2019-ctd, 2020.

Strunk, A., Larsen, N. K., Nilsson, A., Seidenkrantz, M.-S., Levy, L. B., Olsen, J., and Lauridsen, T. L.: Relative sea-level changes and ice sheet history in Finderup Land, North Greenland, Front. Earth Sci., 6, 129, https://doi.org/10.3389/feart.2018.00129, 2018.
Vermassen, F., Bjørk, A. A., Sicre, M. A., Jaeger, J. M., Wangner, D. J., Kjeldsen, K. K., Siggaard-Andersen, M. L., Klein, V., Mouginot, J., Kjær, K. H., and Andresen, C. S.: A Major Collapse of Kangerlussuaq Glacier's Ice Tongue Between 1932 and 1933 in East Greenland, Geophys. Res. Lett., 47, 1-9, https://doi.org/10.1029/2019GL085954, 2020.

Vinther, B. M., Buchardt, S. L., Clausen, H. B., Dahl-Jensen, D., Johnsen, S. J., Fisher, D. A., Koerner, R. M., Raynaud, D., Lipenkov, V., Andersen, K. K., Blunier, T., Rasmussen, S. O., Steffensen, J. P., and Svensson, A. M.: Holocene thinning of the Greenland ice sheet, Nature, 461, 385-388, https://doi.org/10.1038/nature08355, 2009.

Wangner, D. J., Jennings, A. E., Vermassen, F., Dyke, L. M., Hogan, K. A., Schmidt, S., Kjær, K. H., Knudsen, M. F., and Andresen, C. S.: A 2000-year record of ocean influence on Jakobshavn Isbræ calving activity, based on marine sediment cores, Holocene, 28, 1731-1744, https://doi.org/10.1177/0959683618788701, 2018.

Wood, M., Rignot, E., Fenty, I., An, L., Bjork, A., van den Broeke, M., Cai, C., Kane, E., Menemenlis, D., Milan, R., Morlighem, M., Mouginot, J., Noel, B., Scheuchi, B., Velicogna, I., Willis, J. K., and Zhang, H.: Ocean forcing drives glacier retreat in Greenland, Sci. Adv., 7, eaba7282, https://doi.org/10.1126/sciadv.aba7282, 2021.

Young, N. E. and Briner, J. P.: Holocene evolution of the western Greenland Ice Sheet: Assessing geophysical ice-sheet models with geological reconstructions of ice-margin change, Quaternary Sci. Rev., 114, 1-17, https://doi.org/10.1016/j.quascirev.2015.01.018, 2015.

Zekollari, H., Lecavalier, B. S., and Huybrechts, P.: Holocene evolution of Hans Tausen Iskappe (Greenland) and implications for the palaeoclimatic evolution of the high Arctic, Quaternary Sci. Rev., 168, 182-193, https://doi.org/10.1016/j.quascirev.2017.05.010, 2017. 